FIU Law Review

Spring 2010

\title{
Can Unions Use Worker Center Strategies?: In an Age of Doing More With Less, Unions Should Consider Thinking Locally but Acting Globally
}

Jennifer Hill

Florida Immigrant Advocacy Center

Follow this and additional works at: https://ecollections.law.fiu.edu/lawreview

Part of the Other Law Commons

Online ISSN: 2643-7759

\section{Recommended Citation}

Jennifer Hill, Can Unions Use Worker Center Strategies?: In an Age of Doing More With Less, Unions Should Consider Thinking Locally but Acting Globally, 5 FIU L. Rev. 551 (2010).

DOI: https://dx.doi.org/10.25148/lawrev.5.2.14

This Article is brought to you for free and open access by eCollections. It has been accepted for inclusion in FIU Law Review by an authorized editor of eCollections. For more information, please contact lisdavis@fiu.edu. 


\title{
Can Unions Use Worker Center Strategies?: In an Age of Doing More With Less, Unions Should Consider Thinking Locally but Acting Globally
}

\author{
Jennifer Hill*
}

In May 2010, UNITE HERE Local 355 held a meeting in Miami called "Rise Up for Haiti." Most of this local union's members are lowwage Haitian workers trying both to support their families here and deal with the devastating impact of January's earthquake on family and home communities in Haiti. As preparation for the meeting, a Haitian union activist spent weeks conducting in-depth interviews with 250 other Haitian members. ${ }^{2}$ Members identified two priorities for union action. First, members - many of whom have faced wage stagnation since September 11, 2001 - asked that their union aggressively seek wage increases in bargaining because workers need more money if they are to support their families here and to increase remittances home. ${ }^{3}$ Second, members wanted their union to be actively engaged in advocating for comprehensive immigration reform. ${ }^{4}$

Jennifer Hill is Director of the Workplace Justice Project at the Florida Immigrant Advocacy Center, which she created as a Skadden Fellow in 2007. Ms. Hill worked as a union organizer for roughly 12 years with local unions of the Service Employees International Union in Tennessee and Florida, with the AFL-CIO Southern Region, and with the United Electrical, Radio, and Machine Workers in Iowa. Ms. Hill helped found a worker center in Michigan, the Washtenaw County Workers Center, and a women's labor solidarity organization, STITCH. Many thanks for information, feedback, and suggestions to Fran Ansley, Ian Robinson, Dave Dobbie, Jen Luff, Marnie Mahoney, Ellen Dannin, Ken Casebeer, Mary Gundrum, J.J. Rosenbaum, Liz O’Connor, Rachel Micah-Jones, Lysie Joanem, and Wendi Walsh. Special thanks to Professor Kerri Stone, the FIU Law Review staff, and interns Amy Shenstone, Kristin Drecktrah, and Jorge de Cardenas.

1 UNITEHERE.org, UNITE HERE Local 355 Rises Up for Haiti, May 21, 2010, http://www.unitehere.org/detail.php?start_row=20\&ID=3225.

2 Kaila Heard, Local Union Pledges Support for Haitian Americans, S. FlA. Times, Aug. 21, 2010, available at $\mathrm{http}: / /$ www.sfltimes.com/index.php?option=com_content\&task=view\&id=4485\& Itemid=144.

3 See Douglas Hanks, III, The Fontainebleau Closes for Two Year Renovation; Unite Here's South Florida Union Loses Hundreds of Its Members, MiAmi HERALD, May 17, 2006, available at http://www.hotel-online.com/News/PR2006_1st/Mar06_MiamiUnion.html. For information about the struggle of Haitians in Florida to support loved ones in Haiti, see generally Nadege Charles, In Miami, Haitian Workers Struggle to Send Money Home, Miami Herald, Feb. 26, 2010, available at http://www.miamiherald.com/2010/02/26/v-fullstory/1501040/in-miami-haitians-struggle-with.html.

4 UNITE HERE Local 355 Rises Up for Haiti, supra note 1. 
During the union forum, Haitian workers talked about their extraordinary efforts to make a living on low wages in the United States while sending roughly thirty percent of their wages to support family in Haiti. Even prior to the devastating earthquake in Haiti, this took sacrifice; now, even more support is needed in Haiti. In addition, the lack of a path to citizenship for some workers or family members in this country is a huge obstacle to stability. Responding to the Haitian speakers, Latino workers, local politicians, and union leaders spoke out in solidarity. ${ }^{6}$ The union made the commitment to the two priorities suggested by Haitian members, exorcising the ghost of a past in which Haitians were incompletely included in union activities.?

I attended, together with my young daughter, and felt deep admiration. Unionism at its best brings people together across boundaries, despite suffering, in hope and in struggle. I was happy to be there showing support and involving my daughter in such a moving experience.

Later, thinking about the commitment made to the goals of wage gains and immigration reform, I also felt curious. Could the union win significant wage gains, representing workers at only three out of several hundred South Florida hotels, two casinos, and several airport food service concessionaires? $^{8}$ Although those employers are relatively stable and not likely to move overseas, the economy is rotten, competition is stiff, and unskilled workers - particularly immigrant workers - abound in South Florida. Nevertheless, with a strong effort, the local probably could win wage gains. If so, could the local maintain the bargaining units despite strong competitive pressures over time if wages were set at above-market rates? Will the local also try to win or keep strong contract language on health insurance, retirement, discipline procedures, attendance, scheduling, health and safety, seniority, and other issues? What resources will be required to establish the

\footnotetext{
$5 \quad I d$.

6 Id.

7 See Bruce Nissen \& Guillermo Grenier, Unions and Immigrants in South Florida: A Comparison, in UNiONS IN A Globalized ENVIRONMENT 130, $144-47$ (Bruce Nissen ed., 2002) (describing Local 355's history in relation to immigrants and immigration issues); see also Guillermo Grenier \& Bruce Nissen, Comparative Union Responses to Mass Immigration: Evidence From an Immigrant City, 26 CRITICAL Soc. (No. 1-2) 82, 82-105 (2000).

8 SOUTH FLORIDA WORKERS UNITED (Unite Here Local 355, Miami, Fla.), Fall 2008, available at http://unitehere355.org/pdfs/unite_here_355_newsletter_9_08.pdf (listing three hotels: Fountainebleau, Miami Resort, and Diplomat; two casinos: Isle Casino and Gulfstream; and several food service concessionaires at the Miami and Fort Lauderdale airports as employers with UNITE-HEREcovered bargaining units); see also Airline Catering Workers Rally at Miami Int'l Airport for Better Contracts, ZimBIO, Apr. 6, 2010, http://www.zimbio.com/pictures/5Hqhd5aEScs/Airline+Catering+ Workers+Rally+Miami+Int+1 (listing other food service concessionaires entering into negotiations with UNITE HERE).
} 
leadership, training, staff, and other support to enforce the contracts? If the union also wants to dedicate resources to new organizing and immigration reform, is that possible? Probably not. I do not think that unions, in general, can do all they want to do - all that in a more just world they could and should do - to effect change for most low-wage workers in most areas of the country.

Ralph Waldo Emerson, not thinking about unions at all, said that "[a]11 life is an experiment, and the more experiments you make the better." "Unions, with dwindling numbers and no clear strategy for a turnaround, might accomplish more by experimenting with a model laid out by the worker center movement, one that calls for doing less in bargaining and representation. Unions could increase their relevance to low-income communities, particularly immigrants, by limiting involvement in activities aimed at addressing worksite problems and increasing investment in public policy, leadership development, and organizing work. Though union members would have to sacrifice as the scope of contracts and contract enforcement were diminished, workers and unions also would gain from the new approach. The labor movement could grow stronger if "union voice" were reframed in terms of broad social justice goals, sparking internal discussion and creative strategies to address the common challenges facing members and non-members, immigrants and non-immigrants, and unions as well as other forms of worker organizations. ${ }^{10}$

\section{FOLlOWIng A WORKER CENTER PATH: DOING LESS TO ACCOMPLISH MORE}

The labor movement has been in decline for several decades, ${ }^{11}$ in part because the National Labor Relations Act has failed, either in its terms or in

9 Emerson Journal Entry, Nov. 11, 1842 (on file with author).

10 "Social justice unionism" is an idea that has generated much useful and thought-provoking discussion, sometimes more and sometimes less generous-spirited in understanding the day-to-day work and struggles of union members, staff, and leaders. See, e.g., Bill Fletcher \& Fernando Gapasin,

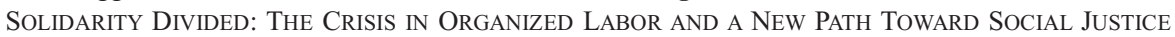
(2008); KiM MOODY, U.S. LABOR IN TROUBLE AND TRANSITION (2008).

11 See Michael Selmi, Unions, Education, and the Future of Low-Wage Workers, 1 U. CHI. LEGAL F. 147,156-58 (2009) (citing Barry Hirsch \& David Macpherson, Note, Union Membership and Coverage Database from the Current Population Survey, 56 Indus. \& LAB. REL. REv. 349 (2003), available at http://unionstats.gsu.edu (follow hyperlink)) (noting the decline of unions even during administrations supposed to be friendly to labor and that unions have declined from a high of $35 \%$ of private non-agricultural workers in 1953 to roughly $25 \%$ in 1973 to less than $8 \%$ now). See also U.S. DeP'T of LABOr, Bureau of LABOr Statistics, Union Members Summary (2010), available at http://www.bls.gov/news.release/union2.nr0.htm, stating:

In 2009, the union membership rate - the percent of wage and salary workers who were members of a union - was $12.3 \%$, essentially unchanged from $12.4 \%$ a year earlier, the U.S. Bureau of 
its application, to provide the nation with an adequately strong and flexible labor law framework. ${ }^{12}$ Unions can and should continue to encourage improvements in labor law, but low-wage workers ${ }^{13}$ cannot wait for labor law

Labor Statistics reported today. The number of wage and salary workers belonging to unions declined by 771,000 to 15.3 million, largely reflecting the overall drop in employment due to the recession. In 1983, the first year for which comparable union data are available, the union membership rate was $20.1 \%$, and there were 17.7 million union workers.

12 See LANCE COMPa, UnFAIR AdVANTAGE: WORKERS' FREEDOM OF ASSOCIATION IN THE UNITED States Under InTERnATIONAL Human Rights Standards 244-70 (2000); LANCE COMPA, Discounting RightS: WAL-MART'S VIOLATION OF US WORKERS' Right TO FREEDOM OF Association 16-21, 65-74 (2007); James A. Gross, Broken Promise: The Subversion of U.S. Labor Relations Policy 1947-94 (1995); Mark Barenberg, The Political Economy of the Wagner Act: Power, Symbol, and Workplace Cooperation, 106 HARV. L. REV. 1379, 1412-30 (1993); James J. Brudney, Reflections on Group Action and the Law of the Workplace, 74 TEX. L. REV. 1563, 1575-80, 1588-91 (1996); Cynthia L. Estlund, The Ossification of American Labor Law, 102 ColuM. L. REV. 1527, 1527-28, 1532-40 (2002); Julius Getman, The National Labor Relations Act: What Went Wrong; Can We Fix It?, 45 B.C. L. REv. 125, 141-42 (2003); James Gray Pope, How American Workers Lost the Right to Strike, and Other Tales, 103 Mich. L. REV. 518, 550-53 (2004); Julie Yates Rivchin, Building Power Among Low-Wage Immigrant Workers: Some Legal Considerations for Organizing Structures and Strategies, 28 N.Y.U. REV. L. \& Soc. Change 397, 410-16 (2004); Theodore St. Antoine, Federal Regulation of the Workplace in the Next Half Century, 61 CHI.-KENT L. REV. 631, 647-54 (1985); Paul Weiler, Promises to Keep: Securing Workers'Rights to Self-Organization Under the NLRA, 96 HARV. L. REV. 1769, 1769-86 (1983).

13 There are several ways to define low-income workers: those making minimum wage, those at or below the poverty line, those at or below $200 \%$ of poverty-level wages, and those making some defined amount less than the median wage. For purposes of this paper, the characteristics of lowincome sectors that make them hard to organize and sustain in bargaining units is more important than the precise definition of low-income. Michael Selmi defines "low-wage workers [as] equivalent to those individuals who earn approximately $\$ 12$ an hour in 2009 wages. This wage represents the midway point between poverty-level wages and the median wage." Michael Selmi, Unions, Education, and the Future of Low-Wage Workers, 1 U. CHI. Legal F. 147, 151 (2009). Selmi also notes that immigrants, including: documented and undocumented Latinos, single mothers, and African-Americans are disproportionately represented in the low-wage population. Id. at 151-52; see also JOHN SCHMITT, CTR. FOR ECON. \& POL'y RESEARCH, UNIONS AND UPWARD MOBILITY FOR WOMEN WORKERS 3 n.9 (2008), available at http://www.cepr.net/documents/publications/unions_and_upward_mobility_for_women_ workers_2008_12.pdf. Schmitt studied low-wage workers who were employed primarily in fifteen lowwage occupations, excluding occupations with very few workers or very low unionization rates; the list included "food preparation workers, cashiers, cafeteria workers, child-care workers, cooks, housekeeping cleaners, home-care aides, packers and packagers, janitors, grounds maintenance workers, nursing and home-health aides, stock clerks, teachers' assistants, laborers and freight workers, and security guards," which together make up $15 \%$ of the workforce. Id. at 8 . In these occupations, among civilian workers, undocumented workers are prevalent; for example, undocumented workers make up 17\% of food preparation workers, $20 \%$ of cooks, $22 \%$ of maids and housekeeping cleaners, $20 \%$ of packers and packagers, and $25 \%$ of grounds maintenance workers. Id.; see also JEFFREY S. PASSEL, THE SizE AND CHARACTERISTICS OF THE UNAUTHORIZED MIGRANT POPULATION IN THE U.S. 11-13 (2006), available at http://pewhispanic.org/files/reports/61.pdf. In addition, many retail workers are low-wage workers, and retail is a large category. Id.; see also HEATHER BOUSHEY ET AL., UNDERSTANDING LOW-WAGE WORK IN THE UNITED STATES 10 (2007), available at http://www.inclusionist.org/files/ lowwagework.pdf. 
renewal. $^{14}$ What the labor movement needs now is more experimentation that challenges deeply-held beliefs about what a union looks like and does. Although unions have explored innovative organizing strategies in recent years, post-organizing bargaining and representation programs remain largely unchanged. Ideas from the dynamic worker center movement could prove useful, albeit perhaps unsettling.

Worker centers generally work with low-wage, immigrant workers. ${ }^{16}$ The centers tend to focus on industries with low union density, where

14 Kate Bronfenbrenner and Rob Hickey have analyzed data on union tactics and win rates in organizing campaigns and emphasized the need for unions to more consistently run comprehensive organizing campaigns. I believe there is the same urgent need for unions to radically restructure their post-organizing operations. See Kate Bronfenbrenner \& Rob Hickey, Blueprint for Change: A NATional ASSESSMENT OF WinNing Union ORganizing Strategies 55 (2003) (“Unions cannot wait for labor law reform, for a more favorable economic climate, or more favorable political environment before they begin to utilize this more comprehensive, multifaceted, and intensive strategy in all their organizing efforts, inside and outside the NLRB process.").

15 The dynamism of the worker center movement is in part shown by the rapid increase in the number of centers around the country, from fewer than five in 1992 to roughly 160 by 2007 . See Janice Fine, A Marriage Made in Heaven? Mismatches and Misunderstandings Between Worker Centres and Unions, 45 BRIT. J. INDUS. REL. 335, 339 (2007).

16 Worker centers, though fairly recent as a widespread phenomenon, have generated varied and fascinating accounts. See Janice Fine, Worker Centers: Organizing Communities at the Edge of the Dream (2006) [hereinafter Worker Centers]; JenNifer Gordon, Suburban Sweatshops: THE FIgHT FOR IMMIGRANT RightS (2005); Saru Jayaraman, ROCing the Industry: Organizing Restaurant Workers in New York, in THE New IMMIGRANT URBAN WORKFORCE: INNOVATIVE MOdELS FOR LABOR ORGANIZING 143 (Sarumathi Jayaraman \& Immanuel Ness eds. 2005); Ai-jen Poo \& Eric Tang, Center Stage: Domestic Workers Organizing in the Global City, in The New Urban ImMigranT WORKForCe 105, 105-18 (2005); Sameer M. Ashar, Public Interest Lawyers and Resistance Movements, 95 CAL. L. REV. 1879, 1891-92 (2007) ; Janice Fine, Worker Centers: Organizing Communities at the Edge of the Dream, 50 N.Y.L. SCH. L. REV. 417 (2005-2006) [hereinafter Edge of the Dream]; Janice Fine, A Marriage Made in Heaven? Mismatches and Misunderstandings between Worker Centres and Unions, 45 BRIT. J. INDUS. REL. 335 (2007); Janice Fine, Jeff Grabelsky \& Victor Narro, Building $a$ Future Together: Worker Centers and Construction Unions, 33 LAB. STUDIES J. 27 (2008); Jennifer Gordon, We Make the Road by Walking: Immigrant Workers, The Workplace Project, and the Struggle for Social Change, 30 HaRV. C.R.-C.L. L. REV. 407 (1995) [hereinafter Gordon, We Make the Road]; Daisy Ha, Comment, An Analysis and Critique of KIWA's Reform Efforts in the Los Angeles Korean American Restaurant Industry, 8 ASIAN L.J. 111 (2001); Alan Hyde, New Institutions for Worker Representation in the United States: Theoretical Issues, 50 N.Y.L. SCH. L. REV. 385 (2005); Saru Jayaraman, Letting the Canary Lead: Power and Participation Among Latina/o Immigrant Workers, 27 N.Y.U. REV. L. \& Soc. Change 103 (2001-2002); Steve Jenkins, Organizing, Advocacy, and Member Power: A Critical Reflection, 6 WorkIngUSA 56, 56-89 (2002); Peter Kwong, Chinese Staff and Workers' Association: A Model for Organizing in the Changing Economy?, 25 Soc. POL'Y 30 (1994); Benjamin Marquez, Organizing Mexican-American Women in the Garment Industry: La Mujer Obrera, 15 WOMEN \& POL. 65 (1995); Victor Narro, Impacting Next Wave Organizing: Creative Campaign Strategies of the Los Angeles Worker Centers, 50 N.Y.L. SCH. L. REV. 465 (2005-2006); Victor Narro, Finding the Synergy Between Law and Organizing: Experiences From the Streets of Los Angeles, 35 FORDHAM URB. L.J. 339 (2008); David Rosenfeld, Review Essay, Worker Centers: Emerging Labor Organizations--Until They Confront the National Labor Relations Act, 27 BERKELEY J. EMP. \& LAB. L. 469 (2006); Emily Stein, Organization Profile, The Workplace Project, 50 N.Y.L. ScH. L. REV. 607 (20052006); Lizzy Ratner, The New Domestic Order, ThE NATION, Sept. 28, 2009, available at 
employment often is subcontracted, temporary, or otherwise marked as contingent, or where small "shops" - a convenient term for worksites predominate. ${ }^{17}$ Worker centers operate on a scale and in industries inhospitable to traditional collective bargaining. The forces of domestic and global capitalism create intense competitive pressures. Individual firms and workers appear and disappear quickly, even as the need for someone to clean, weed, carry, cook, or care for others remains relatively constant. These shifting sands make the landscape a difficult one in which to build worker power. ${ }^{18}$

Unions and worker centers have developed a model of organizing that relies on employment laws, rather than labor laws, to insulate nascent efforts among low-wage workers. If, in addition, unions were to look to worker center experiences in post-organizing stages of union life, even more would change. Unions would do less inside organized shops in order to do more outside the shops. Union leaders would abandon the beliefs that a union must take on shop-floor problems in order to represent workers adequately, that a union must use shop-floor structures for leadership development, and that a union must use bargaining as the key tool to raise standards.

Instead of bargaining for as strong and comprehensive a contract as possible, the union would bargain for a limited contract. A grievance

http://www.thenation.com/article/new-domestic-order; Worker Center Strategies (N. Am. Alliance for Fair Employment (NAFFE), Working Paper, 2002), available at http://web.archive.org/web/ 20041205075617/www.fairjobs.org/docs/wp1.htm.

17 Jonathan P. Hiatt \& Lee W. Jackson, Union Survival Strategies for the Twenty-First Century, 12 THE LAB. LAW. 165, 167 (1996). Hiatt and Jackson distinguish between "core" jobs, where workers perform "a narrow set of functions [defined by firms] as those worth being performed by permanent, full-time employees," and the "periphery," where workers perform functions "through a variety of 'contingent' arrangements which negate or minimize the firm's legal and social obligations owed to those performing these services for the firms." Id. at 167. Among the sorts of contingent relationships that place jobs in the periphery are "disposable" temporary or part-time workers, workers hired through an intermediary employee leasing, temporary agency, or service contractor. Id.

18 See Eduardo Porter, Unions Pay Dearly for Success, N.Y. TimES, Jan. 29, 2006, at B4 (describing union decline as in part a function of prior success at raising wage rates, putting unionized employers in jeopardy as economic globalization and industry transformations have increased competitive pressures); John Seewer, Unions Target New Groups of Workers, Hous. CHRON., Mar. 23, 2007, available at http://www.chron.com/disp/story.mpl/ap/fn/4656012.html (noting that "[t]he new faces of unions are immigrants [and other] groups who are unlikely to lose their jobs to overseas workers" and describing some steps unions are taking to change their approach.”). In Houston, SEIU organized 5300 janitorial workers after several years and millions of dollars expended in the campaign, but new organizing is not turning the tide. Labor's acceptance of the need for changed strategies makes up part of the "end of the globalization debate," whereby worker rights activists increasingly frame demands in terms of global norms rather than in terms of "the democratic self-determination of national communities" and are part of "global networks of activists who intervene in struggles surrounding the terms of economic and social life in communities throughout the world. ..." Robert Howse, Book Review, The End of the Globalization Debate: A Review Essay, 121 HARV. L. REV. 1528, 1533-34 (2008). 
procedure still would be important. The union, however, would limit the contract's guarantees and the grievance procedures' reach primarily to rights already existing under employment statutes, such as minimum wage, overtime, and anti-discrimination. The union would not seek dramatic wage increases. To the extent shop-floor issues were confronted, workers would lead the struggle with little or no on-site support from union staff. Union rights, such as dues deduction, union leave, or organizing rights, would be a priority in bargaining insofar as those rights supported outsidethe-shop activities such as policy advocacy, new organizing, and workforce development activities. As a result, the "union difference" 19 for low-wage workers would not be defined primarily in terms of wage and benefit increases, unless increases were won through across-the-board policies benefiting members and non-members alike. The union would still be a mechanism for workers to have a "voice," but that voice would mostly speak outside the shop.

At first, this seems crazy. Workers who arguably most need wage increases and broad protections would not get them. ${ }^{20}$ Unionists would be abandoning - or at least radically departing from - the approach traditionally taken and the tools traditionally used to improve the work lives of members. They would set aside their belief in a fundamental progression shop-floor fights generate strong leaders, who win workplace improvements, which motivates members for action outside the worksite, which together builds a strong union. Instead, unionists would see communitybased activities as equally or more important paths to building leadership and strength. Unions would select issue-based fights with a priority on mobilizing unorganized workers, making policy gains, or otherwise amplifying the impact of the union's limited resources.

There are four reasons for exploring a worker center approach. First, unions do not have a significant presence in low-wage industries in the private sector, and that presence goes from low to negligible in areas with low overall union density. Workers unlucky enough to be in subcontracted,

19 See, for example, the AFL-CIO website defining the "union difference" primarily in terms of pay and benefit increases above non-union rates. AFL-CIO, The Union Difference, http://www.aflcio.org/joinaunion/why/uniondifference/ (last visited Aug. 27, 2010); see also JOHN SCHMITT, CTR. FOR ECON. \& POL'y RESEARCH, UNIONS AND UPWARD MOBILITY FOR LATINO WORKERS (2008), available at http://www.cepr.net/documents/publications/latino_union_2008_09.pdf.

20 I don't think it is possible to make an argument about what workers "need" unions for the most, but one often hears an argument that unions are needed most for those subject to the most blatant exploitation. The argument is commonly made that unions are most effective in making improvements for lower-wage workers. The "union difference" represented by wage improvements is highest for lowwage workers and declines as the wage level increases. See, e.g., John Schmitt, CTR. For Econ. \& Pol'y Research, The Union Advantage FOR LOW WAge Workers (2008), available at http://www.cepr.net/documents/publications/quantile_2008_05.pdf. 
temporary, part-time, or other contingent relationships, in small shops, or in heavily immigrant workforces, are left out almost as completely as are the categories of workers excluded under the NLRA. ${ }^{21}$ There is little indication that unions can even maintain their marginal presence in low-wage, heavily-immigrant sectors, much less increase it, by following the current path.

Second, worker centers have had an impact greater than their size would lead one to expect. Leading worker centers have demonstrated that at least on a small scale - membership, leadership, energy, and modest improvements in workplace standards can be achieved without a traditional shop-floor-based program. Unions traditionally have used a strategy of taking wages out of competition by organizing a high percentage of workers in a market or industry and bringing up wages across the board. Thus, no one employer suffers the sort of competitive disadvantage that it would if it were alone in raising wages. That strategy has proved untenable in the era of globalization, as unionization rates have declined and competition has intensified. Worker centers are developing structures that offer a route to self-organization and collective action to low-wage workers. Worker centers also are creating programs that aim to improve skills, raise standards, and amplify the collective voice of workers, particularly immigrants. Because worker centers are quite different from unions - tiny in

21 National Labor Relations Act (NLRA), 29 U.S.C. § 152(3) (2006) (“The term 'employee' . . shall not include any individual employed as an agricultural laborer, or in the domestic service of any family or person at his home, . . . or any individual having the status of an independent contractor, or any individual employed as a supervisor ... ."); see also LANCE COMPA, UnFAIR ADVANTAGE: WORKERS' FreEdom of AsSOciation Under InTERnAtional Human Rights STANDARds 244-70 (2000). Domestic workers are organizing, under the umbrella of the National Domestic Worker Alliance in worker centers across the country. See, e.g., Lizzy Ratner, The New Domestic Order, The Nation, Sept. 28, 2009, available at http://www.thenation.com/article/new-domestic-order. For information on farm labor organizing, despite the farmworker exclusion, see W.K. BARGER \& ERNESTO REZA, THE FARm Labor Movement in the Midwest (1994); Susan Ferriss \& Ricardo SANDOval, The Fight In the Fields: Cesar Chavez AND the FARMWORKers Movement (1997); David GRIFFITHS, ED

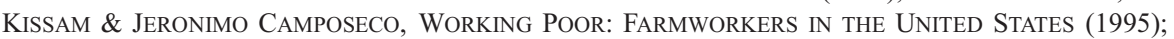
David Griffith, Challenges to Farmworker Organizing in the South: From the Southern Tenant Farmers Union to the Farm Labor Organizing Committee's Mt. Olive Campaign, 26 Culture \& AgRICUlturE 25 (Spring/Fall 2004). For an analysis of collective bargaining opportunities among contractors, see Elizabeth Kennedy, Freedom from Independence: Collective Bargaining Rights for Dependent Contractors," 26 BERKELEY J. EMP. \& LAB. L. 143 (2005).

22 See Tom Gallagher, A More Perfect Union: Organized Labor's Critical Role in Comprehensive Immigration Reform, GCIR ISSUE FoCUS: ORGANIZED LAB. \& CIR (Grantmakers Concerned with Immigrants and Refugees (GCIR), Sebastopol, Cal.), Feb. 2010, at 2, available at http://gcir.org/system/files/GCIR_unionarticle_final.pdf (quoting AFL-CIO General Counsel Jon Hiatt saying, "Even if every current union organizing campaign were successful, he says, 'The number of new workers organized would still far fall short of reflecting a major gain in union density or even a clear trend in that direction.'"). 
size, not self-funded, and not mandated to be governed democratically ${ }^{23}-$ translating worker center approaches to a union scale and context will be difficult. Making the transition, however, could help unions create a path to sustainability and even growth.

Third, many experiments would not depend on changes in the NLRA, its interpretation, or its administration through the NLRB. There is not much in the NLRA, as currently written and interpreted, to encourage unions to engage in creative experimentation. On the other hand, the NLRA does not appear to prevent a union from exploring a worker-center-like approach, and the NLRB would be most helpful if, in addition to restoring rights that have been eaten away by anti-worker interpretations of the Act, the Board made an effort not to stymie such innovation. ${ }^{24}$ Unions could and should engage in experimentation to move away from traditional approaches to bargaining and representation in low-wage sectors. ${ }^{25}$

Fourth, unions have struggled to develop what many call a "social justice unionism" approach. This approach is one in which the core value of collective action is preserved while activities, structures, and strategies adjust to very difficult economic and political realities. For example, unions have been criticized for adopting a "business" model of unionism, in which enforcing contract gains for existing members was prioritized over organizing new members or mobilizing members as activists. Many unions shifted to an "organizing" model, shifting resources toward new organizing and political action in which worker-activists were deeply involved. Because membership growth has proved both more difficult and less transformative in itself than hoped, unions continue to search for ways to maintain relevance and power. Following the worker center model, unions might be able to root discussions of change in the "view from the bottom," where immigrant workers live in an environment from which unions are

23 The differences in scale, democratic accountability, legal and ethical obligations, funding, structural constraints, and organizational cultures and history are enormous. I have found (albeit with limited experience) many activists on the worker center side of the labor movement to overestimate the innovativeness of their organizing methods, to underestimate the obligations (legal and ethical) of union leaders to their members, and to carry out their work, wonderful though it is, in an environment from which experienced union organizers and leaders largely are absent. This is not intentional, of course, but it is a pity. Worker centers depend for their impact in large part on the existence and support of unions and have much to learn from unions and unionists too.

24 Many commentators have described possible routes to restore rights that have been undermined by courts or the Board in earlier years. Labor law renewal and labor law reform both are tremendously important. See Ellen Dannin, Should the National Labor Relations Act Be Retired?: NLRA Values, Labor Values, American Values, 26 BERKELEY J. EMP. \& LAB. L. 223 (2005); Ellen Dannin, Not a Limited, Confined, or Private Matter-Who is an 'Employee' Under the National Labor Relations Act, 59 LAB. L.J. 5, 8 (2008).

25 The move away from traditional approaches likely could and should be made in higher-wage units also, but my concern here is with low-wage sectors. 
largely absent. By imagining new structures and programs from scratch, in a sense, unions might be more free to move away from activities that made sense for other workers in other times but no longer make sense.

\section{FOR LOW-WAGE WORKERS, HARDLY A UNION IN SIGHT}

In $2009,13.6 \%$ of public and private sector workers nationally were part of a bargaining unit, but only roughly $8 \%$ of full-time low-wage workers were represented by unions. ${ }^{26}$ Most low-wage earners worked for employers with fewer than 100 employees, and they worked in service and hospitality jobs. ${ }^{27}$ On first reflection, $8 \%$ does not sound like an insignificant amount, but that figure is deceptive because it masks stratification among low-wage jobs and geographical differences in union density that leaves many individuals, especially undocumented immigrants, in an unprotected frontier.

A good place to start to understand the numbers is with a description of the core-periphery distinction. The quickening pace of globalization, technological advances, and shifting markets has affected all aspects of the economy. $^{28}$ Major industries have undergone massive restructuring and reengineering of their processes and strategies. Firms have responded by adopting more flexible systems of employment, and companies have become "leaner," outsourcing or spinning off peripheral activities, employ-

26 Barry Hirsch \& David Macpherson, Union Membership and Coverage Database from the Current Population Survey, available at http://unionstats.gsu.edu (follow hyperlink); see also WiLLIAM A. Carroll \& G. Edward Miller, U.S. Dep'T Health \& Human Servs., Full-Time Poor and Low INCOME WORKERS: DEMOGRAPHIC CHARACTERISTICS AND TRENDS IN HEALTH INSURANCE COVERAGE, 1996-97 To 2005-06 (2009), available at http://www.meps.ahrq.gov/mepsweb/ (enter "Full-Time Poor and Low Income Workers" into search field; follow hyperlink).

In 2005-06, 7.9 percent of full-time low income workers belonged to a union, 45.2 percent worked in an establishment with fewer than 25 employees, 24.6 percent worked in an establishment with 26 to 99 employees and less than one-third (30.1 percent) worked in an establishment with 100, or more, employees. Full-time low income workers were most likely to work in service industries with 26.4 percent working in professional services occupations and 18.0 percent working in leisure/hospitality/other services.

Id. at iii-v, 11-37. In this study, low-income workers were defined as making $200 \%$ of the poverty level wage or lower. $I d$. at 1 . Note that the $7.9 \%$ includes both public and private sector union members and excludes part-time, temporary, and other workers at the contingent end of the continuum. Id. at 32 (Union Membership, 2005-06). Thus, the real percentage of low-income workers likely would be significantly less than $7.9 \%$.

27 See CARroll \& Miller, supra note 26, at iii-v (Executive Summary).

28 See Howse, supra note 18, at 1529 (adding the globalization of law to Jurgen Habermas' defining of globalization as "the cumulative processes of a worldwide expansion of trade and production, commodity and financial markets, fashions, the media and computer programs, news and communications networks, transportation systems and flows of migration, the risks generated by large-scale technology, environmental damage and epidemics, as well as organized crime and terrorism"). 
ing fewer full-time workers, and relying more on contract and part-time employees. Whereas in the Fifties, Sixties, and Seventies, most U.S. workers - especially blue-collar workers - were shielded from competitive unstructured labor markets, today, a growing number of these workers are not. ${ }^{29}$ As the world has moved away from a model in which "the work of firms was done by employees of the firm," 30 companies have turned to "contingent" workers, including independent contractors. In contingent relationships, users of labor are separated from workers by intermediary employers; contingent workers include independent contractors, employees provided through temporary agencies or labor service providers. ${ }^{31}$ These contingent workers "lack the kind of stable attachment to a firm which in the past has been the hallmark of the employment relationship.,"32

With this core-periphery distinction in mind, Jon Hiatt and Lee Jackson, in 1996, sketched out legal obstacles and strategic challenges for unions with reference to four categories of workers: skilled core, skilled periphery, unskilled core, unskilled periphery. The issues they identified impede each group's ability to form and sustain unions. Unskilled workers can be read generally to mean low-wage workers. For example, unskilled core workers are those who are direct employees in low-wage occupations such as most service workers in hotels, nursing homes, and restaurants. Such unions "want a union first and foremost to improve their economic lot" and seem to be just the sort of worker the NLRA should help most. Nevertheless, the sorts of obstacles such workers confront in the organizing process - threats, firings, and other illegal tactics - as well as weak remedies for violations and the ease with which employers can replace strikers undermine the Act's effectiveness. The strategic challenge that emerges as a result of these legal obstacles is to develop better economic pressure tactics so that workers have a realistic chance not just to join a union but to win improvements in negotiations. For unskilled peripheral workers, on the other hand, the biggest problem is bringing workers within the ambit of labor protections at all. Independent contractors, temporary

29 Fine, Edge of Dream, supra note 16, at 429-30.

30 Hiatt \& Jackson, supra note 17, at 167.

31 Id. Contingent workers also may include guestworkers imported from other countries for temporary labor, who represent an extreme pole and also represent an extreme challenge for unions and worker centers. See Jennifer Gordon, Transnational Labor Citizenship, 80 S. CAL. L. REV. 503, 550 (2007) (arguing for a new model of unionism, that would tie immigration status to membership in organizations of transnational workers rather than to a particular employer, and that would provide services, benefits, and rights that cross borders just as the workers do). In exchange for the authorization to work that they would receive as members, migrant workers would commit to the core value of labor citizenship: solidarity with other workers in the United States, expressed as a commitment to refuse work under conditions that violate the law or labor agreements. Id. at 509.

32 Hiatt \& Jackson, supra note 17 , at 167 
and part-time employees, and workers employed by intermediary contractors all are either formally or effectively excluded from protections under the Act. Even where workers could be seen as employees under the Act, the economic reality is that not only the employees but the undercapitalized contractors themselves are disposable. Given the narrow definition of joint employment and broad definition of a third-party neutral under the Act, Hiatt and Jackson explain that low-skilled peripheral workers have a hard time winning union representation.

It is useful to keep the core-periphery distinction in mind. Although stable "core" employment has eroded dramatically since 1996, relatively stable employers, particularly large stable employers, still exist, and in some industries lead employers control big market shares and directly employ many workers. Such employers - large chains of hotels, hospitals, or other businesses employing both high and low-wage workers - are seen as the most desirable organizing targets.

Low-wage workers who are union members are likely to be employed in core rather than peripheral low-wage jobs. In Florida, for example, UNITE HERE represents low-wage workers employed in large bargaining units by Disney, the Fountainebleau Hotel, and the Diplomat Hotel, as well as in several smaller food concession, hotel, and casino units. ${ }^{33}$ These are big employers, whose employees are more likely to have stable, if low-paid, employment. Their employees are also less likely to be undocumented than those in contingent work or those working for very small employers. Similarly, most Florida members of the Service Employees International Union (SEIU) are employed by reasonably large firms, including hospitals and nursing homes; some work for smaller employers or labor service providers. $^{34}$

Many unions still hold out hope of gaining significant density among core workers in an industry in order to raise wages and benefits without subjecting organized employers to overly-damaging competitive pressures. The old strategy of taking wages out of competition still is the guiding force in decision-making where unions see high-density unionization as an

33 See South Florida Workers United (Unite Here Local 355, Miami, Fla.), Fall 2008, available at http://unitehere355.org/pdfs/unite here 355_newsletter_9_08.pdf; UNITE HERE Local 362, Welcome to Local 362, http://www.uniteherelocal362.org/about.asp (last visited Aug. 27, 2010); SEIU Healthcare, Our History, http://www.seiufhu.org/aboutus/Default.aspx (last visited Aug. 27, 2010); 32BJ SEIU Florida District, http://www.seiu32bj.org/au/District_FL.asp (last visited Aug. 27, 2010).

34 I should note that I worked some time ago for SEIU 1991, a hospital local; worked also for SEIU Florida Healthcare Union, which was at the time a nursing home local and recently became part of $1199 \mathrm{NY}$; and I consulted for a brief time for what was SEIU 11 and is now part of SEIU 32BJ, the building services local. I also am part of a coalition, the South Florida Wage Theft Task Force, which includes UNITE HERE Local 355, SEIU, and the South Florida AFL-CIO. 
achievable goal. Occasionally unions can overcome legal obstacles and bring in new units sufficiently large to increase density significantly. Healthcare and public sector unions in Southern California, for example, won passage of legislation creating a public entity that served as the employer of almost 100,000 homecare workers just for collective bargaining purposes. The fact that unions in a few places have continued to organize new units and win higher-than-market wages and benefits for some groups of workers makes for a double-edged result. Unions take away the lesson that it is smart to focus where the conditions exist for increasing density - markets where unions already are strong enough that political victories are possible, as in California's homecare organizing, or industries where a few key employers control most of the market share and are particularly susceptible to economic pressure tactics available to unions. Unions are not wrong to try to increase density in markets or industries, but there simply is no evidence that unions might ride out the bad times without making fundamental change - something akin to denying global warming because some icebergs haven't melted.

The strategic challenges identified by Hiatt and Jackson are widely applicable because core jobs have declined, and peripheral employment relationships have become more the norm. Unions cannot overcome legal and structural obstacles that make it hard for core and peripheral workers to exert pressure against a common employer. Imagine a typical luxury hotel, which hosts a workforce that includes direct hotel employees, outsourced housekeepers, employees at a "sublet" independent restaurant or coffee shop, and temporary guest workers. Those workers who were formerly the "orphans" of the labor movement because they were excluded from the law's protections - independent contractors, domestic workers, small business employees - now are joined by many others for whom access to protections through traditional organizing and bargaining is practically impossible.

Union numbers are polarized geographically. In low union density, high-immigrant states along the southern U.S. border, for example, union presence is quite low. ${ }^{35}$ Overall private sector union membership runs from a low of two percent in Florida to a high of six percent in Alabama, with Arizona, New Mexico, Texas, Louisiana, and Mississippi falling in between. ${ }^{36}$ These numbers include those workers in higher-wage units, such

35 Eight percent of private sector workers were covered by a union contract in 2009. Hirsch \& Macpherson, supra note 26.

36 Id. (border state statistics for percent of workers covered in a bargaining unit/percent actually members of unions are, respectively: Arizona (4.2\%/3.6\%), New Mexico (4.1\%/3.1\%), Texas 
as transportation, healthcare, and communications. As a result, the percent of low-wage workers in unions is less, perhaps significantly less, than the overall number. Knowing exactly how low the real number of low-wage, unionized workers is - whether one out of every hundred, one out of every thousand, or even fewer of Florida's low-wage workers is a union member - is less important than absorbing the implications of the fact that at least ninety-eight out of every hundred are not.

This leaves undocumented immigrant workers largely out in the cold. Immigrants, particularly undocumented immigrants, tend to be at the bottom of the occupational hierarchy, where union rates are low. ${ }^{37}$ Undocumented immigrant workers are more prevalent in just those low-wage industries with layers of subcontracting or other contingent relationships, or in small, dispersed worksites, making unionization more difficult. ${ }^{38}$ Undocumented immigrants along the Southern border of the U.S. or in other low-density states are isolated from union presence also by geography. Janice Fine painted a startlingly accurate picture when she remarked that low-wage immigrant workers "are as likely to be struck by lightning as to be approached to join a union.",39

There is little evidence that a quick turnaround in union membership numbers is likely, particularly among low-wage workers. ${ }^{40}$ Unions face an uphill battle because the causes of their decline are numerous and complex,

(3.7\%/3.1\%), Louisiana (4.1\%/3.7\%), Mississippi (5.2\%/4.4\%), Alabama (6.9\%/6.0\%), Florida $(2.6 \% / 2 \%))$.

37 See generally Mary Bauer, Southern Poverty LaW Center, Close to Slavery: GUESTWORKER PROGRAMS IN THE UNITED STATES (Booth Gunter ed., 2007), available at http://www.splcenter.org/pdf/static/SPLCguestworker.pdf; ANNETTE BERNHARDT ET AL., BROKEN LAWS, UNPROTECTED WORKERS (2009), available at http://nelp.3cdn.net/1797b93dd1ccdf9e7d sdm6bc50n.pdf; SCOTt Martelle, Confronting the Gloves OfF ECONOMY: AMERICA's Broken LABOR STANDARDS AND HOW TO FIX THEM (Annette Bernhardt et al. eds., 2009), available at http://nelp.3cdn.net/0f16d12cb9c05e6aa4_bvm6i2w2o.pdf; NAT'L EMPLOYMENT LAW PROJECT (NELP), Holding the Wage Floor: Enforcement of Wage and Hour Standards for Low-Wage WORKERS IN AN ERA OF GOVERNMENT INACTION AND EMPLOYER UNACCOUNTABILITY (2006), available at http://nelp.3cdn.net/95b39fc0a12a8d8a34_iwm6bhbv2.pdf; Saskia Sassen, The Informal Economy: Between New Developments and Old Regulations, 103 YALE L.J. 2289 (1994).

38 Benjamin I. Sachs, Employment Law as Labor Law, 29 CARDOZO L. REV. 2685, 2698-99 (2008); see also Katherine V.W. Stone, Legal Protections for Atypical Employees: Employment Law for Workers Without Workplaces and Employees without Employers, 27 BERKELEY J. \& EMP. LAB. L. 251, 279 (2006); PASSEL, supra note 13.

39 Janice Fine, Non-Union, Low-Wage Workers Are Finding a Voice as Immigrant Worker Centers Grow, LABOR NoteS, Aug. 1, 2003, http://labornotes.org/node/735. According to the National Weather Service, there is a 1/6250 chance of being hit by lightning in one's lifetime. National Weather Service, Lightning Safety, http://www.weather.gov/om/lightning/medical.htm (last visited Aug. 27, 2010).

40 See John Seewer, supra note 18 (noting that unions need 500,000 new members a year just to offset annual losses and describing possible changes as unions "offer more job training, serve as a third party to resolve disputes or work more as a support organization for immigrants"). 
including legal obstacles, ${ }^{41}$ effective anti-union campaigning by employers, ${ }^{42}$ increasing numbers of contingent workers with few ties to each other or any employer, organizing campaigns that are inadequately funded or badly-run, ${ }^{43}$ job loss in traditionally unionized sectors, and pressures on workers and unions resulting from economic change and recession. $^{44}$

Much more than union membership numbers or even institutional survival is at stake. Where unions are absent, abuses flourish, and people suffer. Many have reported on the legal violations, including "wage theft," unsafe working conditions, and illegal retaliation. ${ }^{45}$ Low-wage jobs are not essentially like higher-wage jobs, except that they pay less. ${ }^{46}$ Rather, as

\footnotetext{
41 See generally Hiatt \& Jackson, supra note 17.

42 See BRONFENBRENNER \& HiCKEY, supra note 14, at 38.
}

[T]he overwhelming majority of employers in our sample aggressively opposed the union's organizing efforts through a combination of threats, discharges, promises of improvements, unscheduled unilateral changes in wages and benefits, bribes, and surveillance. Individually and in combination, these tactics are extremely effective in reducing union election win rates. Fifty-two percent of all employers in our sample and 68 percent of those in mobile industries made threats of full or partial plant closure during the organizing drive. Approximately one in every four employers (26 percent) discharged workers for union activity, while 48 percent made promises of improvement, 20 percent gave unscheduled wage increases, and 17 percent made unilateral changes in benefits and working conditions. Sixty-seven percent of the employers held supervisor one-on-ones with employees at least weekly, 34 percent gave bribes or special favors to those who opposed the union, 31 percent assisted the anti-union committee, and 10 percent used electronic surveillance of union activists during the organizing campaign. Employers threatened to refer undocumented workers to the Immigration and Naturalization Service (INS) in 7 percent of all campaigns and in 52 percent of cases where undocumented workers were present.

Id.

43 See $i d$. at 54, noting that:

[E]ven in the most difficult contexts, unions can dramatically increase their organizing success when they run more multifaceted strategic campaigns, [but] the majority of unions organizing today still run weak, ineffectual campaigns that fail to build their strength for the long haul. They simply are not doing what is necessary to succeed in the current climate of mobile capital, aggressive employer opposition, and weak and poorly enforced labor laws.

44 See Selmi, supra note 11, at 156-64.

45 Kim Bobo, Wage Theft in America 7-8 (2009); Ana Avendano ET AL., ICED Out: How IMMIGRATION ENFORCEMENT HAS INTERFERED WITH WORKERS' RIGHTS 5-6, 9-10 (2008), available at http://www.nelp.org/page/-/Justice/ICED_OUT.pdf?nocdn=1; ANNETTE BERNHARDT, ET AL., supra note 37, at 2-6. It is worth browsing the websites of the National Employment Law Project (www.nelp.org), Interfaith Worker Justice (www.iwj.org), and AFL-CIO (www.aflcio.org) to learn about the widespread violation of labor and employment laws in low-wage sectors and among immigrant workers. The exploitation of these workers is systematic, constitution "business as usual" in many sectors, but is no less cruel for being common.

46 Descriptions of conditions in the car wash industry are a useful example. See UNITED STEELWORKERS, ClEANing UP THE CAR WASH INDUSTRY 1 (2008), http://assets.usw.org/Organizing/ Documents/car_wash_paper.pdf, explaining that: 
Beth Shulman has noted, "Inadequate wages are just the beginning. Lowwage jobs also mean few or no benefits, rigid schedules, late-night shifts, unsafe and unhealthy conditions, and lack of respect."

\section{The INTERSECTING PATHS OF UNIONS AND WORKER CENTERS}

The picture is not completely bleak, however, in large part because worker centers have emerged as an alternative form of organization concentrated among low-income immigrant workers. Worker centers and unions have experimented with using employment law, such as wage-and-hour or anti-discrimination laws, rather than labor law as a framework for initial organizing efforts, and they have met with some success. Worker centers, sometimes in partnership with unions but more often independently, have mobilized immigrant workers to engage in policy work, improving protections. Unions and worker centers are engaged in discussion, more often separately than together, about changes in membership, funding, programs, and strategies. Unions have not entered into wholesale experiments to change their approach to bargaining and representation, however. These are areas where more work is needed and where worker centers provide a provocative challenge to conventional union practices.

\section{A. The Emergence of Worker Centers}

Worker centers have popped up all over the country in the last twenty or so years. ${ }^{48}$ Janice Fine describes them as "community-based and community-led organizations that engage in a combination of service, advocacy, and organizing to provide support to low-wage workers, [most of which] serve predominantly or exclusively immigrant populations." ${ }^{, 9}$ The current

Working at a carwash can be difficult and even dangerous, especially during the hot summer months when temperatures in Los Angeles approach 100 degrees. Workers are frequently forced to work without safety equipment, training on how to deal with hazards and chemical exposures in their workplaces, clean drinking water, breaks for rest and meals, minimum wages, overtime pay, health insurance, or respect and dignity on the job.

47 Beth Shulman, The Betrayal of Work: How Low-Wage Jobs Fail 30 Million

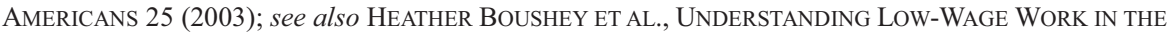
UNITED STATES (2007), available at http://www.inclusionist.org/files/lowwagework.pdf.

48 The literature on worker centers is growing rapidly. See, e.g., supra note 16; see also Immanuel Ness, Organizing Immigrant Communities: UNITE's Worker Center Strategies, in ORGANIZING TO WIN 87, 87-101 (Kate Bronfenbrenner et al. eds., 1998); Charles Heckscher, Organizations, Movements, and Networks, 50 N.Y.L. SCH. L. REV. 313 (2005-2006); Craig McGarvey, Immigrants and Civic Engagement, 94 NAT'L CIVIC REV. 35, 35-41 (2005).

49 Fine, Edge of the Dream, supra note 16, at 419-20. Fine traces the origins of worker centers back to ethnic organizations, faith groups, social service groups, and unions. Similar institutions were seen a century ago - the settlement houses, fraternal organizations, unions, and political parties, and 
wave of worker center organizing is responding to modern immigration and economic trends, including the cross-border movement of low-skilled workers and changes in domestic industries and employment relationships.

Jennifer Gordon, founder of an early worker center, credited labor unions - or, to be more precise, two failures of unions - for spurring the creation of worker centers. ${ }^{51}$ The first was the failure to keep pace with economic and workforce changes during the era of "business unionism",52 from the 1950 s to 1970 s and, in some cases, well beyond. Under the "business unionism" model, unions tended to focus on services for current members rather than organizing; in particular, unions failed to reach out to excluded immigrants, women, and people of color. The second failure occurred when unions, reacting to the decline, justifiably prioritized organizing but adopted, in Gordon's view, a somewhat narrow focus on largescale, "strategic" campaigns.

The aims of strategic campaigning are to organize "on scale" by moving large groups of workers into the ranks of unions. ${ }^{54}$ The key step in

labor unions that aided immigrants in the early-1900s - but they largely faded as immigration declined after the 1920s and as New Deal institutions took on responsibility for providing services to workers.

50 See Jim Pope, Next Wave Organizing and the Shift to a New Paradigm of Labor Law, 50 N.Y.L. SCH. L. REV. 515, 515-16 (2005-2006), characterizing the "paradigm shift in business organization" by explaining:

The old model of geographically fixed, bureaucratic, industrial companies operating primarily in national markets no longer prevails. There is uncertainty about what has replaced it, but some elements seem fairly clear. Flexibility and mobility - including mobility across national boundaries - have replaced predictability and stability as core values in business organization. Corporations increasingly resist long-term attachments of all types. Large-scale bureaucracies, which assign functions to internal divisions, are giving way to core firms that assign functions to "independent" contractors. In employment, the old imperative of retaining experienced workers is now less of a concern than the capacity to shed excess workers or recruit new ones in response to fluctuating market conditions.

51 Jennifer Gordon, Speech at the Conference on: Organizing Migrant and Immigrant Workers, University of Michigan (January 20, 2006) (author's notes). For further discussion of the exclusiveness of labor organizations in the face of transnational migration, see Gordon, supra note 31.

52 See Gordon, We Make the Road, supra note 16, at 424-27. For a discussion of business unionism in comparison with other possible paradigms, see Jim Pope, supra note 50.

53 See Gordon, supra note 51. Unions were hampered by employer opposition and other difficulties that impeded growth in heavily immigrant sectors, of course, but the historical opposition of unions to organizing immigrants, particularly undocumented immigrants, has served as impetus to the increase in worker center organizing. See Saru Jayaraman \& Immanuel Ness, Models of Worker Organizing, in THE New IMMigrant WorkForCe 71 (Sarumathi Jayaraman \& Immanuel Ness eds., 2005); Marion Crain \& Ken Matheny, Labor's Identity Crisis, 89 CAL. L. REV. 1767, 1775, 1828-29 (2001); Pope, supra note 50, at 533.

54 There is a difference between comprehensive campaigning and strategic campaigning, at least as commonly practiced. Comprehensive campaigns incorporate many different sorts of activities in order to maximize the union's chance of overcoming external obstacles to success; a comprehensive 
strategic campaigning is targeting: focusing resources on those employers, sectors, and markets where objective conditions - the size of the bargaining unit, the amount of consolidation of employers in the industry, the financial strength of the target, the likelihood of capital flight - exist that make it possible to believe that one could win recognition and sustain gains. ${ }^{55}$ For instance, a shift in union targeting has been discerned in recent years as unions decreased campaigns directed at "mobile" firms that might easily be moved overseas and increased campaigns directed at non-profit employers. Unions experienced higher win rates where there already was relatively high union density in the region or union presence in other branches of the same firm. ${ }^{56}$ Strategic campaigning considerations pointed unions away from organizing among immigrant workers in unskilled peripheral jobs, and worker centers came in to fill that void. Unions that engaged in organizing in low-wage sectors tended to focus on the core job end of the continuum, while many worker centers either focused on low-wage immigrant communities regardless of industrial sector or focused on workers seen as poor candidates for organizing such as day laborers, domestic workers, or restaurant workers.

\section{B. Convergence: A Common Framework for Organizing}

Unions and worker centers, despite focusing on largely different groups of workers, have moved toward a common model of organizing. Both have come to use employment law claims tactically and, as Benjamin Sachs describes, increasingly as a framework within which to nurture or-

campaign approach has been shown to increase win rates in NLRB election campaigns. See BRONFENBRENNER \& HICKEY, supra note 14. Most union campaigners, however, consider strategic campaigning as first and foremost based on a discipline in targeting that focuses scarce organizing resources on employers, sectors, and markets where power as marked by high-density unionization is seen as objectively achievable. Bronfenbrenner's and Hickey's study bears outs this distinction, noting that the most successful unions used targeting in $71 \%$ of NLRB election campaigns, a rate $25 \%$ higher than the usage of any other single tactic. In other words, successful unions routinely practice strategic campaigning - targeting, targeting, targeting - even while inconsistent in comprehensive campaigning. Id. at $45-46$.

55 In contrast, union organizers have criticized worker centers leaders for focusing on questions of process and role too much and on objective analysis of possibilities for gaining power too little. See Jenkins, supra note 16 , at 58 . Jenkins argues that objective conditions should be taking into consideration, including the "number of people involved in the organizing, the type of work they perform in society, the financial resources they have, the strength of their allies, the power of the forces they are confronting, and the changes being sought. Objective conditions are not static - the entire point of social activism is changing them - but at any given moment, these conditions will limit and define both the form that struggle will take and the power relationships within the campaign between staff and members." $I d$. at 61 .

56 BRONFENBRENNER \& HiCKEY, supra note 14, at 29-35. 
ganizing efforts among low-wage workers. ${ }^{57}$ Unions and worker centers, collectively, have won victories in recent years among childcare, homecare, janitorial, food services, healthcare, construction, and other workers. ${ }^{58}$ Many of these workers are immigrants.

Worker centers began organizing on a small scale, starting with straightforward worker mobilization and direct action tactics to try to resolve problems like wage theft - the nonpayment or underpayment of wages. Worker centers, many of which have employed attorneys or worked closely with law clinics or legal service programs, also often have filed employment claims on behalf of workers. ${ }^{60}$ This has been done for a variety of reasons: as a service to assist workers, a mechanism to draw in new activists, a means of bringing public visibility to issue-oriented activities, and a way to reform employer behavior.

In a parallel track, unions have expanded the use of multiple tactics in comprehensive organizing campaigns, an approach shown, in a series of

57 Sachs, supra note 38, at 2689; see also Benjamin I. Sachs, Labor Law Renewal, 1 HARV. L. \& POL'Y REV. 375, 389-93 (2007).

58 See NAFFE Working Paper, supra note 15 (describing union and worker center campaigns run among homecare workers in California, farmworkers, temporary workers, restaurant workers, day laborers, domestic workers, nursing home workers, and others); Steven Greenhouse, Janitors' Union, Recently Organized, Strikes Houston, N.Y. TIMES, Nov. 3, 2006 (describing organizing campaign and contract negotiations among 5,000 Houston janitors); Steven Greenhouse, Janitors 'Drive in Texas Gives Hope to Unions, N.Y. TIMES, Nov. 28, 2005 (same); Kenneth M. Casebeer, Of Service Workers, Contracting Out, Joint Employment, Legal Consciousness, and the University of Miami, 56 BUFF. L. REV. 1059, 1061-79 (2008) (describing organizing campaign among food service workers at the University of Miami); Mimi Swartz, Shop Stewards on Fantasy Island?, N.Y. TIMES (Magazine), June 10, 2007, available at http://www.nytimes.com/2007/06/10/magazine/10fisher-t.html?; PAM WHITEFIELD, SAlly Alvarez \& YASMin EMrani, CORnell University ILR SCHOOL, IS THERE A WOMEN's Way OF ORGANIZING: GENDER, UNIONS, AND EFFECTIVE ORGANIZING 11-20 (2009), available at http://www.ilr.cornell.edu/laborPrograms/upload/Cornell-womens-way-of-organizing_revised_Layout2.pdf (describing campaigns to organize homebased childcare providers, domestic workers, retail workers, and homecare workers).

59 See generally Ashar, supra note 16 (describing the support a university-based legal clinic has provided to ROC-NY campaigns); Gallagher, supra note 22 (outlining labor's move to embrace immigrant organizing and support worker centers); Hyde, supra note 16; John Seewer, supra note 18 (describing organizing efforts among immigrant construction, childcare, janitors, and others). A particularly interesting campaign is the CLEAN Car wash campaign in Los Angeles, a campaign supported by the United Steel Workers of American, the AFL-CIO, and many local community and legal services organizations. See United STEEL Workers, supra note 46; Narro, supra note 16. An interesting survey of strategies undertaken by community groups/worker centers and one union is laid out in Marnie Brady, Building Movement Project, Alliances for Change: Organizing for the 21st CENTURY (2007), available at http://buildingmovement.org/pdf/Alliances_For_Change.pdf.

60 See Ashar, supra note 16, at 1893 (noting that "[1] aw clinics were among the first legal organizations to collaborate with workers centers," starting with Michael J. Wishnie and Nancy Morawetz at New York University); see also Juliet M. Brodie, Post-Welfare Lawyering: Clinical Legal Education and a New Poverty Law Agenda, 20 WASH. U. J.L. \& POL'Y 201, 225 (2006) (encouraging legal services attorneys to engage in advocacy around worker rights and jobs issues). 
studies by Kate Bronfrenbrenner and others starting in the 1980s, to increase the chances of a union victory. ${ }^{61}$ Among the tactics used by unions has been the development of employment claims, primarily wage-and-hour or discrimination claims. ${ }^{62}$

As worker centers and unions have gained experience in developing employment claims in the context of employer-targeted organizing campaigns, employment law has emerged as a substitute framework for organizing, replacing dysfunctional labor law. ${ }^{63}$ Employment law serves to galvanize collective activity, insulate workers' nascent organizing efforts from employer retaliation, and generate subsequent organizing activities. ${ }^{64}$ In this model, collective claims are framed by workers in terms of existing employment rights. This makes the effort both more grand (as something righteous) and more modest (being aimed at what are really only minimum standards in the law). When framed this way, workers construct "a shared experience of unjust treatment" and "a collective identity based around possession of employment rights." 65 Organizing efforts built around employment law claims may be "generative," because success, at first, produces "more robust forms of collective action." In addition, workers who face employer reprisals for organizing, particularly undocumented workers, have recourse under employment statutes that has been denied under labor law since the 2002 Hoffman Plastics case, although the protections are far from adequate. $^{67}$ There are drawbacks. The employment law model does not offer a vehicle for asserting rights above existing minimum rights. Nor do employment laws completely protect workers from retaliation or create unity where there is a heterogeneous workforce in which groups are affected differently by the assertion of employment rights.

61 See Bronfenbrenner \& Hickey, supra note 14; Kate Bronfenbrenner, The Role of Union Strategies in NLRB Certification Elections, 50 INDUS. \& LAB. REL. REV. 195 (1997); Kate Bronfenbrenner, Employer Behavior in Certification Elections and First Contracts: Implications for Labor Law Reform, in RESTORING THE PROMISE OF AMERICAN LABOR LAW 75 (S. Friedman et al. eds., 1994); Kate Bronfenbrenner \& Tom Juravitch, The Impact of Employer Opposition on Union Certification Win Rates: A Private/Public Sector Comparison (Econ. Policy Inst. Working Paper No. 113, 1994).

62 See Richard Michael Fischl, Rethinking the Tripartite Division of American Work Law, 28 BERKELEY J. EMP. \& LAB. L. 163 (2007).

63 See Sachs, supra note 38, at 2690-91.

$64 \quad I d$.

$65 I d$. at 2728 .

66 Id. at 2735.

67 Hoffman Plastic Compounds, Inc. v. NLRB, 535 U.S. 137 (2002); see also Christopher Ho \& Jennifer C. Chang, Drawing the Line After Hoffman Plastic Compound, Inc. v. NLRB: Strategies for Protecting Undocumented Workers in the Title VII Context and Beyond, 22 HofSTRA LAB. \& EMP. L.J. 473, 496 (2005); Yungsuhn Park, The Immigrant Workers Union: Challenges Facing Low-Wage Immigrant Workers in Los Angeles, 12 ASIAN L.J. 67, 76-81 (2005). 
The Restaurant Organizing Center (ROC) offers an example of how this works. ROC was started after the events of September 11, 2001, by the UNITE HERE union to help the employees of Windows on the World, a restaurant that occupied the top floor of one of the Twin Towers. It then spun off to become an independent group, and has developed a very sophisticated and disciplined approach that includes employer-focused campaigns. In 2004-2005, for example, ROC ran a campaign against two restaurants owned by the Smith \& Wollensky Restaurant Group. The workers complained that they were not paid overtime and experienced discriminatory treatment. ROC helped the workers file a lawsuit, and workers and supporters carried out informational picketing and rallies for months. The employer finally agreed to settle the lawsuit by paying workers some money, committing to follow the law, and allowing limited monitoring to prevent retaliation against worker-leaders. ROC has gone on to run many other employer-focused campaigns in New York and to develop affiliates now running campaigns in other cities. After the employer-focused campaign, workers can continue to be active in training programs, new organizing at other sites, policy advocacy, or the co-operative restaurant.

In the CLEAN Car Wash campaign, an effort currently underway in Los Angeles, a similar organizing model is being deployed. The campaign originated after local legal services and other community groups began identifying problems faced by carwash workers and meeting with resistance in effecting change. ${ }^{68}$ The United Steelworkers of America, with support from the American Federation of Labor and Congress of Industrial Organizations (AFL-CIO), subsequently initiated a "community-wide" campaign to organize a quintessentially hard-to-organize sector. There are roughly 430 carwashes in Los Angeles County, whose employees are mostly immigrants with reported incomes of slightly less than $\$ 13,000$. $^{69}$ The union, together with community groups, has used wage-and-hour and other employment claims to highlight industry problems, pressure exploitative employers, and protect and encourage organizing efforts. The use of employment law claims, first by legal services organizations like Bet Tzedek and, later, also by the Steelworkers, has helped to generate community-wide organizing. ${ }^{70}$ Although no union has yet been recognized, the effort demonstrates the convergence around organizing strategies.

Given this convergence in organizing approaches, it is remarkable to view the almost complete divergence of post-organizing approaches. Worker centers move toward outside-the-shop policy work, supplemented

68 UNITED STEEL WORKERS, supra note 46, at 6.

69 Id. at $2,3,5$.

$70 \quad I d$. at 6. 
by leadership development, participatory research, and workforce development programs, while unions generally deepen their investment in employer-focused activities through the use of bargaining and representation tools.

\section{Divergence: Post-Organizing Strategies}

Unions and worker centers diverge dramatically in post-organizing activities. One way to think about the divergence is that worker centers have grown up living the reality of globalization, immigration, change, uncertainty - as "Davids" trying to figure out how to avoid being stepped on by "Goliath." Unions, on the other hand, have had to relearn that they are, in fact, "Davids" in this new world - even with many times the members and resources of worker centers. Another way to think about the challenge is that unions have tremendous legal obligations to members that worker centers simply do not, namely bargaining, representation, and governance. Unions also have the significantly different challenges of self-funding through dues deduction and winning recognition for new units. For unions to step back and rethink it all, perhaps change it all, while also every day having to do it all, is a herculean task, one consistently underestimated by union critics.

Worker centers recognize that investing significant resources in employer-focused activities after an initial organizing effort is not productive because of their size and resources, because they seek to avoid classification as a "labor organization" under labor laws, and because of the highturnover of both employers and employees in many low-wage industries in a globalized economy. ${ }^{71}$ What worker centers do after initial organizing is change the focus from the employer to outside-the-shop activities. Worker centers generally do not seek to improve standards or address problems on a shop-by-shop basis. They do not tie membership to employer-based units. They cherry-pick activists and move them into training and activities outside the shop, including participatory research, campaigns to create new or

71 Janice Fine explained some years ago the failure of worker centers to develop an "economic strategy" to prospectively change employer behavior or to create ongoing workplace structures and monitoring:

Yet their numbers remain relatively small and they have not been able to regularize membership through systematic collection of dues, leaving them dependent upon outside sources of funding. In addition, very few of the organizations have succeeded so far at large scale economic intervention in labor markets through worker organizing efforts. So far, they seem best at bringing community organizing strategies to bear on labor issues through politics and worst at doing so through economic strategies.

Janice Fine, Non-Union, Low-Wage Workers Are Finding a Voice as Immigrant Workers Centers Grow, LABOR NOTES, Aug. 1, 2003, available at http://labornotes.org/node/735. 
to better enforce existing employment rights, and new organizing efforts directed at other employers. Some provide skills training, and other services including access to low-cost health insurance or legal services; others engage with employers who are interested in "high-road" development activities such as partnering to promote employers willing to respect worker rights and enhance worker skills and opportunities.

Unions have a harder time accepting that established employerfocused approaches may need to be changed. In particular, it is hard for unions to adjust to the virtual impossibility of "taking wages out of competition." Unions have achieved their greatest success in this country by organizing a high density of workers in particular industries and markets, then bargaining so that all the leading employers agree to improvements as high as possible so long as roughly the same across the board. That strategy has allowed union workers to raise wages and benefits while union employers are insulated from undermining competition. ${ }^{72}$ If unions cannot achieve meaningful density - and the number of workers organized in lowwage private sector jobs is abysmally low - then unions have neither the power to win great improvements nor the security of insulating higherpaying employers from competition. What, then, is the proper way to use the key tools of bargaining and representation, two extremely important areas of labor rights and sources of union power? There are not a lot of alternatives to be found, which is why the worker center movement offers a tantalizing view of other strategic possibilities. Even more, stepping away from the traditional approach strikes a blow to the fundamental self-image of unionists as fighting organizations accountable to their base. Asking a unionist to consider the idea that it might be better to not even try to bargain for health insurance benefits for uninsured workers, for example, seems like heretical abandonment of the core union mission of helping workers get what they need and want. Because of both the lack of developed strategic alternatives and the deep-seated commitment to improving members' work

72 See Porter, supra note 18 ("The central problem for unions stems from a core strategy: to organize all the businesses serving a given market, and thus avoid putting unionized companies at a disadvantage relative to their competition. 'One of unions' most fundamental jobs is to take wages and benefits out of competition,' said Bruce S. Raynor, the general president of Unite Here, the union of workers in the textile and hotel industries. While this strategy worked well when a few industrial giants had a virtual lock on the nation's consumers, it started to fall apart as deregulation and trade liberalization took hold in the 1970's, ushering in an era of more intense competition in business."); see also Samuel Estreicher, Trade Unionism Under Globalization: The Demise of Voluntarism, 54 ST. LOUIS U. L.J. 415, 420-21 (2010) ("[U]nions have trouble in competitive markets because, at least from the firm's point of view, they are net cost-adding institutions but are unable to neutralize those costs by organizing the entire product market or by tariffs or 'prevailing wage' laws dampening product market competition."). 
lives, unionists are strongly attached to traditional approaches to bargaining and representation.

Because the traditional strategy relies not only on winning highdensity but sustaining that membership, low-wage workforces present additional obstacles to success in that model. Sustaining membership in lowwage units may be even harder than initial organizing. Sustaining membership requires that: (a) organized employers stay in business; (b) workers get and stay signed up (even in high-turnover units in right-to-work states); (c) low-wage workers pay dues that at least cover the costs of bargaining and representation or, alternatively, higher-paid units continuously subsidize low-wage units; (d) someone covers the costs of future organizing and other activities; and (e) no decertification campaign is run by anti-union forces. If a union negotiates costly improvements in a competitive industry, the employer is placed at a disadvantage vis-à-vis competitors. If a union does not bargain improvements, maintaining membership is more difficult, facing a decertification effort may be more likely, and despite saving costs employer and unit survival still are by no means guaranteed. In any case, where union members' wages are low, their dues likely also are low, and unless those dues are aggregated in very large bargaining units members are unlikely to be able to pay for the cost of ongoing representation activities (much less to cover the cost of bargaining or make contributions to organizing or other union programs). ${ }^{73}$ This can create political tensions, as higherwage members resist ongoing subsidies to lower-wage units, particularly when those low-wage units are not part of the same local or regional grouping. All these challenges make sustainability difficult; something has to give.

Add to this the complexities that arise in heavily immigrant workforces. Consider the problems related to communication. In the nursing homes represented by a local union for which I worked, for example, the workforce included roughly equal numbers of English, Spanish, and Haitian-Creole speakers. Building a staff and leadership team capable of communicating in all three languages was necessary in virtually

73 Imagine a full-time worker making $\$ 8$ per hour. If that person works 2,080 hours in a year, gross pay is $\$ 16,640$. If dues are set even at $2 \%$ of gross pay, annual dues are $\$ 332.80$. A 100 -person bargaining unit, even with full membership, will generate $\$ 33,280$ per year in dues. That money must pay for: all staff support (organizer/representative to do signup, grievances, mobilization, leadership development/training, bargaining, administration, communications); all activist mobilization costs (meetings, trainings, transportation to rallies/events, food, conferences); all per capita dues to the international union or other intermediary bodies (who support centralized functions including: research, organizing, coordination, representation to national and international bodies, policy advocacy, etc.); costs of union elections, board meetings, informational materials; and record-keeping and reporting both to members and leaders and to the government. 
every one of the seventy-plus shops spread across Miami, Tampa, Orlando, and south of Jacksonville. Building multilingual staff and leadership was necessary in shops with fifteen members as well as those with 150 and on day, evening, and night shifts.

Other challenges also arise in the immigrant workforce context. Immigrant members often are concerned with immigration-related issues, and unions must be prepared to deal with those issues. Some immigration related issues include: Social Security no-match letters, scheduling difficulties related to immigration proceedings and supervised release, immigration threats or raids, and the mundane need for translation of information received only in English regarding benefits, or workplace policies. ${ }^{74}$

Unions, despite the tremendous challenges, invest heavily in employer-focused bargaining and representation work even in low-wage, predominantly immigrant bargaining units. Unions generally try to bargain comprehensive contracts to improve wages and benefits above market level and to run shop-floor focused representation programs aimed at enforcing all provisions of the contract. Unions focus leadership development work at building a strong shop-floor leadership corps capable of signing up members (in those states where sign-up is necessary), addressing contract violations, communicating in whatever languages unit members speak, and involving members in activities.

For example, to use again the example of the nursing home local union, we worked with our existing leaders, most of whom at the time were African-American certified nursing assistants (CNAs), to define what made for a "union house." The benchmarks included, as I recall: reaching 70\% membership or higher; recruiting a multilingual, representative leadership team capable of communicating with all workers in all languages on all shifts and in all departments as well as investigating and processing grievances; mobilizing members for actions - wearing stickers, carrying out "marches on the boss," and so on - in support of key grievances; maintaining updated union bulletin boards; participating in orientations and/or otherwise reaching out to new hires; sending representatives to the monthly regional "Dignity Leadership Council" meetings; participating in the political education committee activities; and recruiting and mobilizing a target number of activists to be member-organizers and member-political organizers for organizing, political, and community events. The problems which arose in each of the shops included issues related to seniority, scheduling, safe staffing, training, discrimination, pay, training, promotions, poli-

74 Thanks to Fran Ansley for relating a story about some of these additional difficulties, along with many other words of advice. 
cies about the use of languages other than English in patient care areas, discipline, terminations, disrespect from supervisors, changes in attendance or other policies, and patient care concerns. When negotiations approached, the leadership team and staff developed and collected bargaining surveys, recruited and elected bargaining teams, participated in training, mobilized for contract campaign activities (including in-shop actions and pickets), attended bargaining, mobilized non-bargaining team members to attend bargaining, shared regular updates on bargaining with other workers, and prepared presentations. The leadership and staff also ran regional leadership meetings each month in five regions, developed and carried out education programs, and coordinated phone banks, lobby days, and steward and local elections. The internal organizing staff included two Haitian-Creole speakers, two Spanish speakers, and one monolingual English speaker, and the goals and workload were not at all unusual. The local innovated to improve efficiency by having leaders from shops with a full complement of leaders help out in weaker shops, by building regional leadership development programs, by cross-training staff so they could cover all shops whether nursing home, hospital, or building services - in a geographic area, and by increasing the use of phone and electronic assistance.

Even with greater efficiency, the union failed to meet all its goals. Unions trying to do it all will fail, particularly in low-wage industries where worksite problems abound, where multilingual units are standard, and where round-the-clock shifts and high turnover place additional demands. The lively unions - the ones that try to do the most - will fall short the most. One could say that trying to meet the needs and expectations, both individual and organizational, is desirable even if routinely falling short is the result. More helpful would be rejecting outright the goal of doing it all and engaging members in a difficult discussion aimed at narrowing the range of union goals and activities.

Many union leaders, if asked, likely would say they stick with the traditional employer-focused program because it is the best way to build a strong union and because they are legally obligated to represent bargainingunit members fairly. It is worth thinking about whether a traditional bargaining and representation program really is best for union survival and strength and whether, in addition, the union really is legally obligated to take a traditional approach.

\section{A Worker-Center-Like "Minimum Standards" Program for Unions}

Worker centers move away from employer-focused activity except for what I will call a "minimum standards" program. The reasons for the worker centers to limit employer-focused activity are, in part, quite distinct from the reasons a union might consider making the same move. In part, 
however, the reasons are based in the same reality - the lack of a viable economic strategy in many low-wage industries.

\section{The Worker Center Version}

Worker centers operate in a different financial and legal context. Worker centers must forswear ongoing "dealing with" employers in order to avoid being considered "labor organizations" under the NLRA and other labor laws. This designation would subject them to the ban on secondary boycotts, the extensive financial rules and reporting requirements, limitations on many forms of employer partnerships, and other regulations. ${ }^{75}$ The need to avoid being deemed a "labor organization" under the Act is a negative reason for choosing the minimum standards path. In addition, worker centers do not survive based on membership dues. Thus, the consequences of failing to maintain strong membership at worksites after organizing campaigns are much less significant for worker centers than unions. ${ }^{76}$ The choices made by worker centers, however, do not simply arise from the desire to avoid burdensome restrictions, nor from the lack of a direct nexus between membership and funding. They are strategically-driven decisions. Employer-directed fights - after the initial organizing - are not the only, or the best, mechanism for building the group's ability to engage workers or improve standards.

ROC, for example, defines its strategy as including three-prongs: (1) employer-focused campaigns aimed at winning initial demands framed in terms of employment laws, (2) research that supports policy campaigns to improve industry conditions, and (3) promotion of "high road" practices through partnerships with employers as well as by means of ROC's own worker-cooperative restaurant and training programs. ${ }^{77}$ In an employer-

75 See National Labor Relations Act (NLRA), 29 U.S.C. $\S \S 159(c)(2),(5)$ (2006); id. $\S 401$; id. $\S$ 402(i) (defining "labor organization"); id. $\S \S 431-441$ (setting forth reporting requirements); see also BRADY, supra note 59; Eli Naduris-Weissman, The Worker Center Movement and Traditional Labor Law: A Contextual Analysis, 30 BERKELEY J. EMP. \& LAB. L. 232 (2009); Rosenfeld, supra note 16.

76 It is sometimes frustrating when worker centers and allies focus on the growth of worker center "membership" as a primary accomplishment. Worker centers do many things well. However, creating membership as a meaningful commitment, building large numbers of members, and developing an infrastructure for maintaining that membership are not strong points of this wing of the labor movement. The organizing is on a small scale, with creative work done to amplify the results. Unions could learn a lot from the techniques and strategies utilized by strong worker centers, but unions remain the only significant institution for mass worker membership. For a skeptical view of the effectiveness of worker centers in accomplishing meaningful change, see Heckscher, supra note 48, at 328 (noting that "little clear evidence was found that any new organization has built significant momentum beyond a local level, or has shown a capacity to transform employment relations on a large scale").

77 Naduris-Weissman, supra note 75, at 251-56; see also REMY KHARBANDA \& ANDREA RITCHIE,

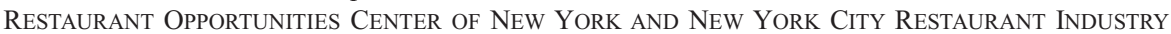


focused campaign, ROC might resolve employment claims by negotiating an agreement that guarantees compliance with existing statutes and, perhaps, includes very modest additional improvements. ROC has negotiated settlement agreements that include, for example, a few days of paid vacation or paid sick leave. ROC is wary of the "labor organization" label, having been brought before the NLRB by an employer seeking to have ROC determined to be a union and subjected to union restrictions. ${ }^{78}$ ROC's monitoring of settlement agreements, as a result, is limited. In order to protect activists from retaliation unlawful under employment statutes, ROC has negotiated to receive advance notice of potential firings and the opportunity to discuss them with the employer. Generally, however, ongoing investment in shop-floor efforts is avoided.

Worker centers like ROC, though small, have had an impact beyond their size. Centers have created new minimum standards by passing local legislation - including laws to combat wage theft, to require paid sick days, to make compliance with employment standards a condition for licensing, and to increase the minimum wage. Worker centers have contributed at the state and national level to reform Department of Labor enforcement, access to special visas for victims of workplace crimes, and guestworker rules. Worker centers also have initiated experiments to model or promote "highroad" development through social entrepreneurial ventures, such as ROC's Colors restaurant that started in New York and now is expanding to other markets, as well as worker cooperatives in cleaning, catering, and landscaping.

What worker centers' experiences have shown is that ongoing employer-focused and shop-floor activities are not necessary for creating a lively organizational culture, promoting worker involvement, or even making very modest gains in wages and benefits. At least on a small scale (like that on which worker centers act), unions' use of outside-the-shop activities can accomplish the same goals. Low-wage, immigrant workers can and will dedicate significant time to engage in training, organizing, and policy advocacy; they will fight for policy gains to improve minimum standards for themselves and others; and they will stay involved over time. Low-wage workers have proved willing to work on immigration- and workplace-related policy issues despite the lack of an employer-focused

Coalition, Behind the Kitchen Door: Pervasive Inequality in New York's Thriving RESTAURANT INDUSTRY (2005), available at http://www.urbanjustice.org/pdf/publications/ BKDFinalReport.pdf; John Lawrence, COLORS Restaurant, DOLLARS \& SENSE, July/Aug. 2006, available at http:// www.dollarsandsense.org/archives/2006/0706colors.html.

78 See Opinion from the N.L.R.B. Office of General Counsel, Case Nos. 2-CP-1067; 2-CB-20643, 2-CP-1071; 2-CB-20705, 2-CP-1073; 2-CB-20787, 2006 N.L.R.B. GCM LEXIS 52 (Nov. 30, 2006). 
program. Guestworkers organized by the New Orleans Workers Center for Racial Justice (who were brought here to work for the Signal Corporation), for example, engaged in a hunger strike, a march to Washington, and lobbying activities to protest the actions of Immigration and Customs Enforcement agents and to promote more fair policies on guestwork. ${ }^{79}$ The members of Domestic Workers United just passed the first-ever state "Domestic Workers Bill of Rights" in New York; this historic piece of legislation won because immigrant domestic workers carried out participatory research, discussed options, developed proposals, learned about the legislative process in trainings, shared testimony, lobbied, and demonstrated, thus making the exploitation of the most isolated of low-wage workers an issue of public importance. ${ }^{80}$

It is possible to characterize a minimum standards program as simply "doing less for members," but the ROC example - as well as examples provided by the New Orleans Worker Center for Racial Justice, Make the Road by Walking, Domestic Workers United, and CASA Maryland - lays out a program of "more" in policy advocacy, leadership development, and participatory research to balance the "less" of in-shop work. There is intense training of leaders, research and reporting to "beat the drum" publicly about worker exploitation, creative mobilization, policy advocacy (to raise workplace standards across-the-board), and sophisticated media and communications work.

Such policy, leadership, and research work also is carried out by unions. The difference is that unions typically try to do outside-the-shop activities and also carry out a comprehensive program of traditional bargaining and representation. The likely result is to reduce, rather than enhance, the ability of the union to sustain low-wage units, which is a bad result for all workers.

79 See Press Release, New Orleans Workers' Center for Racial Justice, Indian human trafficking survivors tear up guest worker visas at White House rally, demand Congressional investigation of US employer, http://www.nowcrj.org/press-releases/indian-human-trafficking-survivors-tear-up-guestworker-visas-at-white-house-rally-32108/; Editorial, A Bitter Guest Worker Story, N.Y. TIMES, Feb. 4, 2010, available at http://www.nytimes.com/2010/02/04/opinion/04thur2.html; Julia Preston, Suit Points to Guest Worker Program Flaws, N.Y. TimeS, Feb. 2, 2010, available at http:/www.nytimes.com/ 2010/02/02/us/02immig.html; Julia Preston, Workers on Hunger Strike Say They Were Misled on Visas, N.Y. TIMES, June 7, 2008, available at http://www.nytimes.com/2008/06/07/washington/07immig.html.

80 See Nicholas Confessore \& Anemona Hartocollis, Albany Approves No-Fault Divorce and Domestic Workers' Rights, N.Y. TIMES, July 1, 2010, available at http:/www.nytimes.com/ 2010/07/02/nyregion/02albany.html; Lizzy Ratner, The New Domestic Order, ThE NATION, Sept. 9, 2009, available at http://www.thenation.com/article/new-domestic-order; Domestic Workers United, Campaigns: NY Domestic Workers Bill of Rights, http://www.domesticworkersunited.org/ campaigns.php; National Domestic Workers Alliance, Campaigns: International Labor Organization Convention, http://www.nationaldomesticworkeralliance.org/campaigns/ilo-convention. 


\section{A Union Version}

A minimum standards program would do more than increase efficiency in bargaining and representation; it would fundamentally change the goals of bargaining and reduce support for addressing worksite problems.

In a worker-center-like program, a union would use collective bargaining to ensure effective protection of minimum employment standards and union rights - but not as a mechanism to win more than very modest additional gains. Unions would support shop-floor fights where there is a legal obligation to engage, either through off-site mechanisms like SEIU's call centers or with very limited staff or lost-time leader support. In general, however, shop-floor fights would not be supported with additional resources. Unions would bargain provisions to protect leadership, deduct dues, and allow leaders time off to participate in non-shop-floor activities, but they would try to avoid negotiating a comprehensive contract. The reason for avoiding the comprehensive contract is to avoid giving rise to the legal obligation to enforce all the provisions included in a typical union contract. This is pragmatic (unions often do not have the resources to adequately enforce comprehensive contracts in low-wage units) and strategic (following a worker center model, the union would choose to devote the bulk of their resources to other pursuits).

The goal is not to reduce the union's efforts to generate collective action aimed at work-life improvements, but to redirect the struggle in a way that makes sense for the industry and the organization, thus allowing unions to have success in representing low-wage immigrant workers. Unions still can be legitimate unions, use the tools provided for under the NLRA, and fight good fights, but, at least in low-wage industries, they would look and act more like worker centers in low-wage industries.

\section{The Benefit of Convergence Around a Worker Center Model}

The benefit - or at least the hope - that a worker center model brings to unionism in low-wage sectors is the opening of possibilities for unions to be a meaningful part of low-wage workers lives and to be social justice organizations. There has been discussion in recent years about what "social justice unionism" means, particularly in light of the continuing decline of unions in the United States and the importance of globalization economically, culturally, and politically.

Bill Fletcher, Jr., and Fernando Gapasin argue that social justice unionism requires: a commitment to collective action that addresses oppression based on class, race, and gender; community-labor collaborations aimed at building political and economic power around a broad range of 
issues (not simply employer-focused bargaining power to address a narrow range of workplace issues); and inclusion in leadership of individuals that reflect the makeup of the working class. ${ }^{81}$ Amy Dean and David Reynolds, discussing revitalization of the labor movement, argue for a "social vision" aimed at: reversing economic and social inequality; promotion of just policies on a wide range of issues from wages to transportation, education, and housing; and a broad community-labor commitment to democratic decision-making that "puts justice for working people at the center of public policy." 82 With this social vision, unions will be "more than narrow defenders of their members' interests at work;" unions will become "highprofile advocates for a new vision of the public good." 83 Bruce Nissen describes social movement unionism in terms of the belief "that the labor movement must return to its 'movement' roots and build a social movement of workers and their allies against corporate domination. . .."

My purpose is not to meld the different definitions, but rather to point out that there seem to be some practical threshold requirements in any view of social justice unionism, and a worker-center-like program could help unions reach the threshold requirements while promoting the sort of discussion and debate necessary for further revitalization efforts. In minimal practical terms, social justice unionism requires that unions are present in low-wage workers' lives by offering a route to membership and/or activism (with or without membership); that unions be able to survive economically; and that unions take on issues, whether in the workplace or elsewhere, that matter to low-wage and immigrant workers. One of the frustrations of much discussion of social justice unionism is that there tends to be a great deal added to the plate of local and international unions without any acknowledgement of the need to reduce and restructure existing activities, much less any prescription for how to do so.

Unions historically have offered a route to collective action, maintained independent self-funding, and taken on a wide range of issues from health and safety to job security to retirement concerns. The traditional employer-focused program, for example, involved building a steward structure that served as the base for ongoing struggle in the shop and supported outside political and community activities. The role of steward is absolutely inspired, and watching a good steward in action is a privilege.

\footnotetext{
81 FLETCHER \& GAPASIN, supra note 10, at 165-85.

82 Amy Dean \& David Reynolds, The New New Deal: How Regional Activism Will RESHAPE THE AMERICAN LABOR MOVEMENT 8 (2009).

83 Id. at 9.

84 Bruce Nissen, Alternative Strategic Directions for the U.S. Labor Movement: Recent Scholarship, 28 LAB. STUD. J. 133, 138 (2003).
} 
Stewards are the worksite leaders, with responsibility for signing up members, leading fights to stop workplace abuses and enforce contract rights, communicating with co-workers and management, and educating and engaging members around a vision of solidarity and justice. Strong stewards are effective advocates, agitators, listeners, and educators. Welldeveloped steward structures are the base of the historic labor claim to be the most vibrant adult education institutions and social justice organizations in the nation.

The heart of the union's historic leadership work is not found, however, in the particular nature of traditional steward activities. Rather, a good steward program engages individuals in struggle over issues that matter in workers' lives both at work and in the community, sets out clear and meaningful responsibilities for consciousness-raising and activism, generates support (or critique) and reflection among workers, and is sustainable because of the dues, the voluntarism, and the day-to-day communication and relationships at the workplace. More generally, unions have succeeded by creating a route to activism, a mechanism for democratic accountability, self-funding, and a joint struggle.

The worker center program, by lowering the resources aimed at the member-focused functions of bargaining and representation and by redefining "union voice" in terms of community based justice struggles, preserves the heart of union collective action but opens a new route to activism. Jennifer Gordon described the participation of low-wage immigrants, including domestic workers, in an early struggle for a New York unpaid wages act. The act was notable because it "was designed by nonvoting immigrants in response to a problem they perceived in their workplaces." W5 Workers like Luz Torres, a domestic worker originally from Colombia, lobbied for the bill. ${ }^{86}$ Fifteen years later, one can see how that sort of inspiring opportunity has been extended to thousands of domestic workers in New York through the struggle for a Domestic Workers' Bill of Rights at the state level, nationally through the formation of the National Domestic Workers Alliance (NDWA), and internationally through the AFLCIO and NDWA joint campaign for a new Decent Work for Domestic Workers convention at the International Labor Organization. ${ }^{87}$ One can imagine, were bargaining and representation commitments reduced and a strategic shift endorsed by workers, similarly restructuring the role and redirecting the work of tens of thousands of union stewards to community-

85 GORDON, supra note 16, at 107.

86 Id. at 106.

87 See supra note 80. 
based struggles of the sort Dean and Reynolds define as the core of "social movement regionalism." 88

\section{THE DUTY OF FAIR REPRESENTATION AND A WORKER-CENTER-LIKE PROGRAM}

For a union seeking to change to a model of scaled-back contractual protections and employer-directed activities, such a change would present legal issues. For present purposes, I will focus on only one area of concern. If a union wanted to bargain for a less-than-comprehensive contract, would anything in the duty of fair representation (DFR) require it to do more? A union, for example, might bargain over fewer than the full list of mandatory topics of bargaining; it might bargain for modest improvements rather than seek significant ones, might agree to a grievance procedure covering only a limited set of rights, or might focus more on union rights outside the shop than union rights in the shop. A union that did so could run afoul of the duty of fair representation. It has proved difficult to define what "fairness" requires. Absent signs of the intent to discriminate against a protected category of workers, the doctrine of substantive fairness should remain limited and yield to union discretion. A union seeking to change its program to a worker-center-like program, however, should invest resources in the sort of conversations and opportunities for feedback that demonstrate support from both majority and minority groups. That would offer protection from a claim of procedural unfairness. More importantly, it would make it more likely that such a change would meet with success.

Unions have a duty to fairly represent workers. While this duty applies in bargaining and representation activities, bargaining is the situation addressed here. ${ }^{89}$ The DFR of members is a judicial creation springing from the union's status as an exclusive representative under the NLRA, as well as from a history that includes ugly instances of discrimination based on race, gender, ethnicity, or other factors. ${ }^{90}$ Unions may not act in a

88 DEAN \& REYNOLDS, supra note 82, at 32.

89 Steele v. Louisville \& N.R.R., 323 U.S. 192 (1944). It is possible that a union could avoid DFR charges in a representation context by not bargaining a broad range of contract guarantees that then triggers a duty to enforce those guarantees. The union's duty to bargain over new issues arising during the life of a contract is somewhat distinct and could present problems, also.

9029 U.S.C. $\$ 159$ (a) (2006), provides:

Representatives designated or selected for the purposes of collective bargaining by the majority of the employees in a unit appropriate for such purposes, shall be the exclusive representatives of all the employees in such unit for the purposes of collective bargaining in respect to rates of pay, wages, hours of employment, or other conditions of employment: Provided, That any individual employee or a group of employees shall have the right at any time to present grievances to their employer and to have such grievances adjusted, without the intervention of the bargaining representa- 
manner that is arbitrary, invidiously discriminatory, or in bad faith in their role as the exclusive representative of a group of workers. ${ }^{91}$ In general, the duty has been interpreted so as to accord great deference to union decisionmaking, ${ }^{92}$ but nevertheless sets limits on a broad range of union activities ${ }^{93}$ and is enforceable through courts or the NLRB. ${ }^{94}$ The underlying goal is to create a "bulwark to prevent arbitrary union conduct against individuals stripped of traditional forms of redress by the provisions of federal labor law."

The great difficulty has been in articulating a rational standard that can be applied with consistency so as to accomplish the protective goal without creating unnecessary litigation or an ineffective mechanical formula. ${ }^{96}$ "Fairness" is the principle that is supposed to limit the power of the union

tive, as long as the adjustment is not inconsistent with the terms of a collective-bargaining contract or agreement then in effect: Provided further, That the bargaining representative has been given opportunity to be present at such adjustment.

See also Marquez v. Screen Actors Guild, Inc., 525 U.S. 33, 44-45 (1998).

91 The duty covers all workers in the unit, whether member or non-member. Syres v. Oil Workers Int'l Union, 350 U.S. 892, 742-43, rev'g 223 F.2d 739 (5th Cir. 1955). The inquiry includes three distinct components: "(1) did the union act arbitrarily; (2) did the union act discriminatorily; or (3) did the union act in bad faith." Ooley v. Schwitzer Div., Household Mfg. Inc., 961 F.2d 1293, 1302 (7th Cir. 1992) (citing Air Line Pilots Ass'n, Int'l v. O’Neill, 499 U.S. 65 (1991).

92 See Humphrey v. Moore, 375 U.S. 335, 342, 372 (1964); Vaca v. Sipes, 386 U.S. 171, 190 (1967); Ford Motor Co. v. Huffman et al., 345 U.S. 330, 337-39 (1953).

93 One commentator described the duty of fair representation as setting "at least an outer limit on the freedom of the representative to juggle claims." Federal Protection of Individual Rights Under Labor Contracts, Note and Comment, 73 YALE L.J. 1215, 1216 (1964).

94 The duty was first defined under the Railway Labor Act but extended to the NLRA. See Huffman, 345 U.S. at 338; Humphrey, 375 U.S. at 342; Wallace Corp. v. NLRB, 323 U.S. 248, 255-56 (1944); Vaca, 386 U.S. at 177. An aggrieved worker may bring suit against the union as a violation of the Labor Management Relations Act, 29 U.S.C. § 185(a) (2006). Under Section 301 of the Act a violation occurs when there is a breach of the contract caused by the union's failure to fairly represent the worker. This type of claim can be made only when the alleged failure is closely linked to the contract. Id. $\S 185$. Alternately, the worker may bring a suit in court under 28 U.S.C. $\S 1337$ as a violation of a law regulating commerce or the worker may file an unfair labor practice charge with the NLRB alleging a violation of 8(b)(1)(A) (making it a violation to restrain or coerce employees in the exercise of their Section 7 right to bargain collectively) or $8(\mathrm{~b})(2)$ (providing that a union may not cause an employer to discriminate against an employee to encourage union membership, among other things). 29 U.S.C. § 158(b)(1)(A); id. $\S 158(\mathrm{~b})(2)$. A claim may be made in relation to the union's actions in bargaining, processing grievances, or otherwise acting as the exclusive representative of workers. Id. $\S$ 158(b)(1)(A); id. § 158(b)(2); see also Julia Penny Clark, The Duty of Fair Representation: A Theoretical Structure, 51 TEX. L. REV. 1119 (1973); Archibald Cox, The Duty of Fair Representation, 2 VILL. L. REV. 151 (1957); Gerry S. Gibson, The NLRB and the Duty of Fair Representation: The Case of the Reluctant Guardian, 29 U. FLA. L. REV. 437 (1976-1977).

95 Vaca, 386 U.S. at 182.

96 Clark, supra note 94; Cox, supra note 94; Mayer G. Freed et. al., Unions, Fairness, and the Conundrums of Collective Choice, 56 S. CAL. L. REV. 461 (1983); Alan Hyde, Democracy in Collective Bargaining, 93 YALE L.J. 793 (1984); Federal Protection of Individual Rights Under Labor Contracts, supra note 93 , at 1216 . 
to do the bad things it might do, without overly constraining the union in doing the good things it should do. Nailing down what substantive or procedural rules guarantee that outcome has been a tricky task.

The DFR has been interpreted to require substantive fairness, most often in cases where contracts were discriminatory on their face or in effect. ${ }^{97}$ In a worker-center-like minimum standards program, a claim based in substantive unfairness might arise if one group gained more than another in bargaining. Of course, some groups always gain more than others in bargaining; a wage increase of twenty-five cents an hour is a greater proportional increase for lower-wage workers than for higher-wage workers, and an increase to a night shift differential does not benefit day or evening shift workers at all.

In the context of a move to a minimum standards contract, the union might negotiate a provision requiring the employer to follow all applicable federal, state, and local employment statutes and to provide for arbitration of violations. Such a provision would not give employees any rights they did not already have, but would give workers a faster track to enforce their rights. ${ }^{98}$ Imagine that there are a minority of workers in the unit that are paid more than minimum wage while the majority is routinely shortchanged so their wages fall below minimum wage. The union's decision to negotiate an arbitration provision distributes a quick method for redress equally to lower- and higher-paid workers, but the only ones likely to see a wage increase are the lower-paid workers previously subjected to minimum wage (and possibly other) employment law violations. Such an unequal benefit, however, would not likely be found to be a breach of a duty of fair representation. $^{99}$ If there were evidence of invidious intent to discriminate

97 See Bowman v. Tenn. Valley Auth., 744 F.2d 1207 (6th Cir. 1984). Discrimination based on politics also has been an issue. See Clark, supra note 94 (analyzing a distinct line of cases dealing with political discrimination culminating in Truck Drivers Local 568 v. NLRB, 379 F.2d 137 (D.C. Cir. 1967)).

98 The value of a fast track to address violations of minimum wage or overtime rights should not be discounted, given the prevalence of wage theft in low-wage sectors. See MARTELLE, supra note 37. Samuel Estreicher has suggested that unions be allowed to trade some protections under employment law, specifically the FLSA. Samuel Estreicher, Freedom of Contract and Labor Law Reform: Opening Up the Possibilities for Value-Added Unionism, 71 N.Y.U. L. REV. 827, 848-49 (June 1996); see also Stewart Schwab, The Union As Broker of Employment Rights 41-54 (Cornell Law Faculty Working Papers, 2009), available at http://scholarship.law.cornell.edu/cgi/viewcontent.cgi?article=1057\& context $=$ clsops_papers.

99 See Huffman, 345 U.S. at 339 (finding no bad intent where union contract granted military veterans greater seniority credit, and non-veteran employees sued); see also Williams v. Pac. Maritime Ass'n, 617 F.2d 1321, 1330 (9th Cir. 1980) (stating union has not violated duty of fair representation when, in good faith, it bargains for better terms of employment for one group than for another). 
against categories of people protected under other civil rights laws, however, the outcome likely would be different. ${ }^{100}$

If there were no intent to discriminate, but there were a disparate impact, it is difficult to predict whether a DFR claim would succeed. Imagine, for example, that the minority of higher-paid employees were all or mostly of one race (or gender, age, national origin, or any other protected category under existing civil rights laws); the majority of lower-paid workers were of a different race (or other protected category). Such a provision, distributing greater benefits to lower-paid than higher-paid workers, likely would survive a challenge, as it would not be arbitrary. Bargaining representatives have not generally been found in breach of the duty of fair representation on the grounds of arbitrariness because a "wide range of reasonableness" is presumed, making this claim difficult unless the union can offer absolutely no rational explanation for the provision. ${ }^{101}$ The rationale - ensuring a minimum standard of employment rights - likely would pass muster.

The situation would be more complicated if an existing contract were being modified in which the union was seen to have expropriated a legitimate expectation of "vested" benefits. ${ }^{102}$ If a union, for example, had in place seniority rights granting more experienced workers preferences in scheduling and leave time, but the union wanted to abandon that part of the contract in order to reduce its obligations to represent workers in workplace disputes, there could be a problem. Demonstrating a motive that did not target any particular group for reduced "vested" benefits would be important. The bad faith component in DFR cases is tied to motive, "allow[ing] unions to make [even] unfounded decisions as long as there is no evidence of deliberate wrongdoing.,"103

Courts and the Board also have considered whether fairness can be determined based on the procedure that a union uses to reach the challenged decision. The case law is muddled in the area of procedural fairness, but the questions are important for any union considering a change. ${ }^{104}$ It is hard to identify what procedures are best suited to promote fairness and how one

100 In addition to Steele v. Louisville \& N.R.R., 323 U.S. 192, 203 (1944), see Glover v. St. LouisS.F. R. Co., 393 U.S. 324, 330-311969) (finding allegations of race discrimination sufficient). (1991).

101 Huffman, 345 U.S. at 338; see also Air Line Pilots Ass'n, Int'l v. O’Neill, 499 U.S. 65, 67

102 Freed et al., supra note 96, at 482-84.

103 Clark, supra note 94, at 1132.

104 To some extent, the outlines of the duty of fair representation in general are muddled and have stayed muddled for thirty-plus years. See Griffin v. UAW, 469 F.2d 181, 182 (4th Cir. 1972) ("The phrase 'duty of fair representation' is a legal term of art, incapable of precise definition . . . [b]ut pronouncements made from time to time by the Supreme Court, articulating the somewhat hazy contours of the union's obligations, do furnish a measure of guidance."). 
ensures the procedures are followed in good faith rather than just mechanically. Another part of the problem is that to determine what procedures are fair, one has to decide how to define a fair outcome. Freed, et al., argue that there is no procedure capable of guaranteeing a fair outcome, which they define as one that best reflects the desires of the bargaining unit members. ${ }^{105}$ They review several methods, none of which would adequately ensure the optimal result in the face of the complexities of bargaining. ${ }^{106}$ Moreover, they assert that ultimately fair process arguments rest on substantive judgments about fairness, subject to all the problems that afflict the substantive fairness standards. ${ }^{107}$

One way out of the box is to suggest that fair procedures are not those that result in an outcome that reflects the optimal mix of bargaining unit member preferences, but rather the one that gives minorities the best "fighting chance" to be heard. Clark, for example, argues that "instead of reviewing the union's choice of alternatives for reasonableness or fairness, courts should review the union's decisionmaking process. If the union gave fair consideration to the complaining employees' interests and based its decision on rational factors, the court should not interfere."108

Labor laws do not require procedures such as ratification of proposed agreements, ${ }^{109}$ the use of any particular mechanisms to develop contract demands, or compliance with whatever procedure is established in the union's constitution. ${ }^{110}$ The duty of fair representation could be viewed as, perhaps, the appropriate mechanism for reading into labor law additional requirements for " "responsible collective bargaining".,"11

105 That approach fails to take into account the non-voting workers to whom the union, in my view, also owes a solidarity obligation. Unions, in bargaining, not only are representing the members of the bargaining unit but also are taking into consideration the resources, interests, and desires of other members and the interests and desires of unorganized workers. Unit members, depending on the moment, the pressures, the demographics, and the quality of leadership and communication, may or may not take such factors into account. Certainly - for all sorts of reasons - there is a history of whitedominated bargaining units failing to take into account the interests of people of color who were not part of the bargaining unit or even the union as a whole. That, however, raises issues of leadership and governance that aren't the issue here.

106 Freed et al., supra note 96, at 506-23.

107 Id. at 507 (arguing the "conscientious union" approach to procedural fairness results in ad hoc judgments about substantive fairness like those that afflict the substantive fairness approach).

108 Clark, supra note 94, at 1132.

109 Hyde, supra note 96, at 801 (drawing a connection between the treatment of ratification in DFR claims and an earlier decision that lack of ratification could not prevent a contract bar except if ratification was required by the contract); see also Appalachian Shale Prods. Co., 121 N.L.R.B. 1160, 1162-63 (1958).

110 Hyde, supra note 96, at 805-06, 819-21, 851-55.

111 Id. at 807 n.57. Hyde criticizes "authoritarian" bargaining in which individual rights are not protected in order to "foster responsible collective bargaining." Hyde, supra note 96, at 807 n.57. Hyde would require negotiations to be highly democratic and participatory in order to be "responsible." Id. 
Arbitrariness may be found where there is no evidence of procedures that allow for consideration of different interests, and bad faith may be found where procedures are used only to give the impression of fair consideration. $^{112}$ In Retana v. Apartment, Motel, Hotel and Elevator Operators Union, Local No. 14, for example, a Spanish-speaking worker sued the union because union representatives failed to adequately inform her and other Spanish speakers about the contract, did not bargain for bilingual supervisors, and failed to process grievances on behalf of other Spanish speakers. The court said that Retana could have stated a claim by indicating bad motivation, but even without evidence of bad motivation a claim also was possible based solely on the union's lack of process to ensure Spanish-speaking workers could participate in bargaining and representation activities. ${ }^{113}$

In a minimum standards program, the union would face possible opposition from members in preparing demands, negotiating compromises, and approving a proposed agreement. From the outset, the union would be driving a bargaining program that would seem odd to many or most workers - bargaining for less than the maximum potential level of guarantees and in-shop resolution of disputes. Supporters of a minimum standards program would be doing this because of a commitment to a long-term strategy, but it is not a strategy that would necessarily be supported by all. It almost certainly would not be supported without a great deal of discussion.

If the union were following a worker center model and if the situation involved negotiations for a first contract following an initial organizing campaign, a commitment to the organizational strategy would have been secured during the organizing campaign. In order to safeguard the union against possible DFR claims, discussing overall strategy during the organizing campaign (and even securing some form of a written commitment to the minimum standards/social justice program) would be very use-

112 Hyde cites a number of cases in which procedural failures have caused courts to allow DFR claims to be pursued. Alexander v. Int'1 Union of Operating Eng'rs, 624 F.2d 1235, 1241 (5th Cir. 1980); Branch 6000, Nat'l Ass'n of Letter Carriers v. NLRB, 595 F.2d 808, 811-12 (D.C. Cir. 1979) (failure to include non-members in demand preparation referendum); Frederickson v. System Fed'n No. 114 of Ry. Employees Dep't, 436 F.2d 764, 769 (9th Cir. 1970) (failure to follow union negotiator's policy statement); Frenza v. Sheet Metal Workers Int'l Ass'n, 567 F. Supp. 580, 586-87 (E.D. Mich. 1983) (failure to follow ratification); see also Boilermakers Local 202 (Henders Boiler), 300 N.L.R.B. No. 4 (N.L.R.B. Sept. 28, 1990) (failure to allow non-members to vote in a referendum on holidays); Lodge No. 10, IAM, 257 N.L.R.B. No 71 (Aug. 5, 1981) (failure to allow non-member storeroom attendants to vote on scheduling).

113 See Retana v. Apartment, Motel, Hotel \& Elevator Operators Union, Local No. 14, 453 F.2d 1018, 1023-24 (9th Cir. 1972). But see Kolinske v. Lubbers, 712 F.2d 471, 481 (D.C. Cir. 1983) (finding union-employee relations outside scope of DFR). 
ful. Likewise, whether or not the union constitution requires ratification, holding - and winning - a ratification vote would be a safe practice, as would communicating regularly during negotiations. ${ }^{114}$

What would happen if, after committing to the minimum standards program during organizing, the workers balk during bargaining? ${ }^{115}$ Can the union fire its bargaining team and skip ratification? Must the union talk with workers to reach agreement about an approach? The answer is an unqualified maybe. One union was found not to have breached its duty when it refused to let bargaining unit members participate in a ratification vote, knowing they were hostile to the leadership's position. ${ }^{116}$ Another was found to have breached its duty when it ignored three separate votes against the terms of a proposed agreement and for completely distinct proposals. ${ }^{17}$ If a union were to take a calculating view toward member participation, given these cases, then the leaders either would have to win and maintain the support of the members through ongoing participatory activities or the leaders would have to avoid allowing any expression of member preferences in order not to be held bound by them.

Of course, discouraging worker input or expression during bargaining is a far riskier strategy in the long run. In recent years, there has been a great deal of debate about whether one union or another is affording members of minority blocs a chance to be heard or whether union leaders are

114 See Frenza, 567 F. Supp. at 586.

115 Another interesting set of questions concerns what happens if the members of a bargaining unit reject a proposed contract based on minimum standards and want a traditional program. In a worker center context both the organization and the workers are free to walk away at any moment, except insofar as a worker center has assumed responsibility as the legal representative of the workers in an employment lawsuit. Worker centers, however, have been largely unable to attain large memberships, unable to make membership a particularly meaningful commitment in terms of dues or other responsibilities, and unable to coordinate effectively across regions or nationally. This suggests that some constraints on exit might be useful or even necessary to maintain large numbers or coordinate across jurisdictions. Nevertheless, interesting variations in both the meaning of membership and the constraints on exit by both organization and individual are worth pursuing given the much broader range of experimentation taking place. Similarly, the two types of organizations sit far apart on a continuum of financial support - unions depend almost completely on dues and worker centers on grants and, to a lesser extent donors or dues groups of each sort are exploring diversifying their funding bases in different ways and/or coordinating more closely while maintaining distinct, specialized funding sources and roles. Of course, the legal constraints arising from labor, tax, anti-trust, and other areas of law are implicated. It is a lively area of both field experimentation and analysis.

116 Mfg., Maint., Indus. \& Gen. Constr. Workers, Local Union No. 652, 237 N.L.R.B. 442, 443 (1978) (no breach of duty of fair representation found when ratification vote excluded work crew of a "vociferous opponent of both the Union hierarchy and the contract").

117 Farmer v. Local 1064, United Catering, Rest., Bar \& Hotel Workers, 99 L.R.R.M. (BNA) 2166, 28 (E.D. Mich. 1978). 
adequately responsive even to majorities in some situations. ${ }^{118}$ The latter issue is really a question of democratic governance, not a duty of fair representation issue, and union supporters should be wary of inviting intervention in internal decision-making by means of the DFR doctrine. Similarly, unions should be careful to follow procedures for input and to demonstrate responsiveness to member concerns during bargaining in order to avoid creating the grounds for greater judicial intervention.

Participatory engagements - talking about strategy, involving workers and leaders in actions, maintaining communication, seeking democratic buy-in - are ends in themselves, not simply tactically important activities to protect against possible DFR claims. That sort of engagement is a hallmark of much worker center activity and should be emulated, if it is not already, in order to guarantee the union's success. These practices also are important in order to maintain a leadership cadre willing to move into new organizing and policy fights after negotiations are concluded. Strategic needs and commitment to collective action should cause a union to invest in participatory and democratic mechanisms, whether or not procedural DFR claims are possible.

\section{CONCLUSION}

Are unions already moving in the direction of worker-center-like programs? There are interesting collaborations, and some of them have served to coordinate efforts to organize but have not necessarily brought internal change to membership structures, bargaining, or representation work. In the car wash campaign, new organizing strategies are being explored, but it is unclear whether the Steelworkers, if they were to win the right to represent workers, also would change their post-organizing

118 Most of the criticism in recent years has been aimed at the Service Employees International Union for perceived failures of union leaders or staff to be adequately accountable to the wishes and interests of members. Generally the issues have been framed as failures of democratic governance, and fascinating tensions concerning centralization, decentralization, coordination, and democratic governance in a complex environment have emerged. In a distinct vein, however, one can imagine DFR claims being raised - and in some arenas meeting a favorable reception - in an effort to require union leaders not only to allow minorities a chance for input but also to more clearly respond to majority concerns, so long as those concerns are not overtly discriminatory. See, e.g., Steve Early, Reutherism Redux: What Happens When Poor Workers' Unions Wear the Color Purple, LABOR Notes, Sept. 2004; Steve Early, Where is the Real Debate About Labor's Future?, LABOR NOTES, Oct. 2004; Amy Offner, Boston Janitors Say Strike Settlement Is No Victory, LABOR Notes, Dec. 2003, at 1, 11; Ralph Thomas, Union, Nursing Home Alliance Team Up, SEATTLE TIMES, Mar. 5, 2007, available at http://archives.seattletimes.nwsource.com/cgi-bin/texis.cgi/web/vortex/display?slug=seiu $05 \mathrm{~m} \& d a t e=$ 20070305. See also, for different perspectives, RICK FANTASIA AND KIM VOSS, HARD WORK: Remaking The American Labor Movement (2004); VAnessa Tait, Poor Workers' Unions: REBUILDING LABOR FROM BELOW (2005). 
approaches. Some construction unions have collaborated with day laborer or guestworker centers, and these efforts involve rethinking basic membership terms to some extent. ${ }^{119}$

Unions, however, should be engaging in fundamental, internal change even if not partnered with a worker center; the restructuring job is primarily an internal challenge, one that cannot be achieved simply by finding a worker center ally. SEIU has put significant work into creating more efficient representation structures, using a call center model, and has narrowed bargaining goals in some sectors, such as nursing homes. SEIU has been widely criticized as undemocratic both because of the nature of the changes and the manner in which changes were pursued. If one can put aside the concerns about democracy and governance for a moment (not to minimize, but to separate those concerns), then the substantive changes themselves look a lot like a worker-center-like program. Call centers can provide advice in the appropriate language whether or not each individual shop has equally-well-trained and multilingual leaders; workers and leaders still can take on shop-floor problems, but the union would not invest in on-site staff or other support, in general. The narrowing of contract goals is a step toward both diminishing post-bargaining obligations for representation and strengthening the union's ability to focus on outside-the-shop activities like policy advocacy, participatory research, creative mobilizations, or new organizing. Worker centers fight very limited employerfocused fights; when unions, operating at a scale thousands of times larger, move toward a similarly-limited engagement, the challenge of building worker support is much greater. The worker-center-like program, whether run on a small scale by a worker center or on a large scale by a union, still requires intense dialogue and engagement.

Other unions have sought to create occupational union membership even where the NLRA does not protect such forms. In New York, for example, the Retail Wholesale and Department Store Union (RWDSU) is experimenting with an occupational form of membership for retail workers, a huge segment of unorganized, mostly low-wage workers. ${ }^{120}$ If the union could develop a sustainable strategy, outside the framework of the NLRA

119 Fine, Edge of Dream, supra note 16.

120 See "What is RAP," Retail Action Project website, http://www.retailactionproject.org/ pagedetail.php?id=3 (last visited Aug. 27, 2010). The site describes the RAP project as: "a membership organization for retail workers dedicated to improving the wages and working conditions in the retail industry. We are a growing network of retail workers who work together to win living wages, benefits and respect in all retail stores. RAP is a community labor partnership of the Retail, Wholesale and Department Store Union (RWDSU) and Good Old Lower East Side (GOLES)." See also Whitefield, supra note 58, at 13-14. 
(which currently restricts non-construction unions from using the occupational union form), then workers would be able to join no matter for which employer they worked or even whether they were currently employed. With such a membership base of retail workers, the union might be able to productively use a mix of employer-focused policy and workforce development activities like that developed for restaurant workers by ROC. The possibilities are exciting, but the pace of change too slow from the perspective of the many workers essentially left out of the labor movement.

There is a parallel between unions and newspapers, both venerable institutions facing challenges to their very survival. Old-fashioned newspapers are dying, but does that mean the death of good journalism? If good journalism can only take the form of local, daily print newspapers, then yes. If there is a core of journalism that can be preserved in a different form or forms, then, perhaps no. Unions are dead in most low-wage sectors in many regions of this country, or so close to dead that the difference is hard to tell, at least from the perspective of an unorganized worker. Unionism in the traditional form does not appear likely to re-emerge any time soon. If there is a core of unionism, it is the central notion of collective action. Can unionism be meaningful to low-wage workers by preserving collective action but changing the form it takes? Emulating worker centers could in some respects be an important ingredient, and the time to experiment is now. 